\title{
An Assessment of Telecommunications Regulation Performance in the European Union ${ }^{\#}$
}

\author{
António Afonso * and Carla Scaglioni ${ }^{* *}$
}

May 2006

\begin{abstract}
We assess the performance of National Regulatory Authorities across 16 EU countries regarding economic regulation in telecommunications sector, by constructing a so-called Composite Regulatory Performance Indicator for regulatory aspects such as effectiveness of the national regulatory system, effectiveness of the dispute settlement body, general market access conditions and application of remedies in markets for narrowband voice, mobile, broadband and business services. This composite indicator is the output measure used in the DEA non-parametric approach. The computation of efficiency scores allows to rank the NRAs and to detect some room for improvement in terms of efficiency gains for each national authority.
\end{abstract}

JEL Classification Numbers: C14, L51, L96, O52

Keywords: technical efficiency, DEA, telecommunications, regulated industries, National Regulatory Authorities, European Union

\footnotetext{
\# We thank Andrea Gavosto, Guido Romano, Stefano Barbato and Emma Galli for helpful comments, and Sandro Bazzanella and Sara Hogg for providing the data. The opinions expressed herein are those of the authors and do not necessarily reflect those of the authors' employers. Carla Scaglioni wishes to thank the Public and Economic Affairs Division of Telecom Italia for its hospitality.

${ }^{*}$ ISEG/UTL - Technical University of Lisbon, Department of Economics, and UECE - Research Unit on Complexity in Economics, R. Miguel Lúpi 20, 1249-078 Lisbon, Portugal, email: aafonso@iseg.utl.pt. UECE is supported by FCT (Fundação para a Ciência e a Tecnologia, Portugal), under the POCTI program, financed by ERDF and Portuguese funds.

** MEF-DPS-UVAL, Regional Public Accounts, Via Gaeta 3, 00185 Rome, Italy, email: carla.scaglioni@tesoro.it.
} 


\section{Contents}

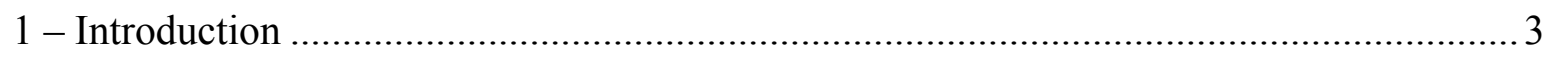

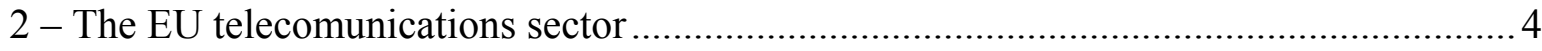

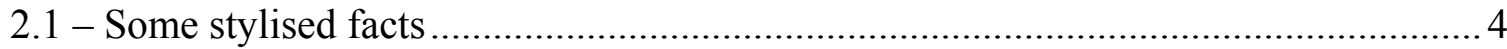

2.2 - Regulatory framework and study motivation................................................. 9

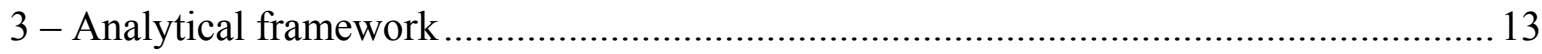

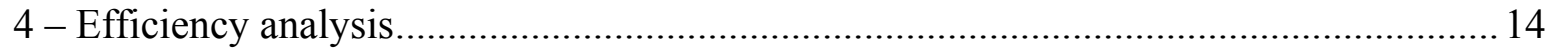

4.1 - Composite Regulatory Performance Indicator (CRPI) .................................... 14

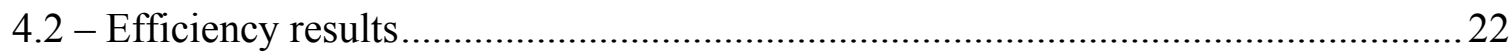

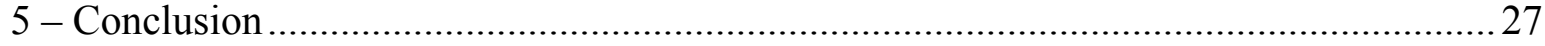

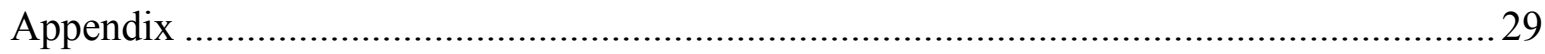

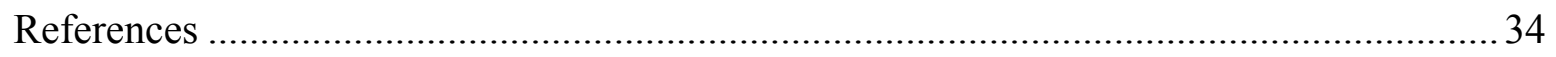

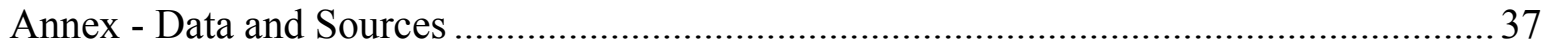




\section{1 - Introduction}

The regulation of infrastructure industries, such as electricity, gas, water supply and telecommunications, was affected by significant changes over the past decades, with an increase in attractiveness of the so-called incentive regulation methods. ${ }^{1}$ In the European Union (EU) these sectors have been liberalised and most of the traditionally publicly owned incumbent monopolies have been privatised. Consequently, National Regulatory Authorities (NRAs) have been created in order to ensure a successful evolution towards competitive markets, regulate and supervise the relations between incumbents and new comers, who initially dependent on incumbents' services. Mainly, it has been argued that policy-makers need to increase the credibility of regulatory commitments in order to encourage new investors to enter in the market (Levy and Spiller, 1996; Majone, 2001). Accordingly, both theoretical and empirical works have emphasised that the governments' commitment of not interfering with property rights is crucial for attracting long term investments and developing sustainable growth levels (Henisz, 2002).

Moreover, according to the New European Regulatory Framework, one of the main tasks required from the NRAs is to promote efficient investment and innovation in the field. Regarding these features, Nicoletti and Scarpetta (2005) have, recently, underlined how countries with restricted public ownership in the sector and few barriers to entry have experienced improving productivity, as compared with countries in which regulation limits competition and public firms are prevalent.

In this paper we assess the performance of National Regulatory Authorities (NRAs) across 16 European Union countries. We take into account the effective economic regulation in the telecommunications sector, by constructing a so-called Composite Regulatory Performance Indicator (CRPI) for leading regulatory aspects such as effectiveness of the national regulatory system, effectiveness of the dispute settlement body, general market

\footnotetext{
${ }^{1}$ For a review see Newbery (2000).
} 
access conditions and application of remedies in markets for narrowband voice, mobile, broadband and business services. Using such composite indicator as an output measure, we then use a non-parametric approach, Data Envelopment Analysis (DEA), to estimate efficiency scores for the NRAs in 2004. We are able then to distinguish NRAs that might qualify as "performing well" from those where some improvement might be possible. To our information, this is a first effort of checking efficiency and effectiveness in European NRAs using non-parametric analysis.

The paper is organised as follows. In section two we give a brief overview of the European Union telecommunications sector, notably by providing stylised facts and motivation for the study. Section three presents the analytical framework. In section four we compute the composite regulatory performance indicators and perform the DEA calculations. Section five provides conclusions.

\section{2 - The EU telecomunications sector}

\section{1 - Some stylised facts}

Between 1997 and 2002 the European Commission submitted eleven reports on the implementation of the package of directives liberalising and harmonising the European markets for telecommunications services. Following a review, the Commission proposed in 2000 five directives to replace the twenty-five or so instruments then in force, together with a decision on the use of spectrum for communications services. Four of the directives subsequently adopted by the European Parliament and Council were required to be transposed into national law by 24 July 2003. They are the Framework, Access and Interconnection, Authorisation and Universal Service and Users' Rights Directives ${ }^{2}$. In parallel with this process the Commission adopted a directive on the basis of Article 86 of the Treaty (Competition Directive), consolidating previous directives liberalising the provision of services on these markets.

\footnotetext{
${ }^{2}$ The remaining directive, known as the e-Privacy or Data Protection Directive, was due for transposition by 31 October 2003. We report in detail the Directives' contents in Appendix Table A1.
} 
This course of actions has naturally influenced the telecommunications sector in Europe. According to European Commission (2006) and OECD (2005), e-communications markets are now characterised by an increasingly positive outlook. In 2003 the size of the telecommunication services market in the OECD increased to around USD 950, notably due to wireless communications and the Internet. On the one hand, revenues from mobile services reached USD 336 billion. On the other hand, the impact of the Internet has generated a new revenue stream through subscriptions but has also amplified the demand for fixed network access, backbone capacity and leased lines.

Competition is increasing in most markets, bringing higher benefits in terms of price, quality and innovative services to consumers. Across the OECD, although the process of liberalisation has been faster in the wireless sectors, there were in 2004 no countries with a monopoly for the provision of fixed network services (see Table 1).

The sector is emerging from a period of cost cutting and debt reduction. For the EU countries, overall revenue growth in the sector has been estimated between 3.8 per cent and 4.7 per cent for 2005 , while the fixed data and mobile services have shown strong growth of 8.3 per cent and 5.9 per cent respectively. This is mainly due to the fact that traditional fixed line carriers are losing market share in favour of mobile operators that are offering rising quantities of airtime in return for a flat monthly fee as well as advanced value added services. On average the mobile penetration rate is now at 92.8 per cent for the EU 25 and the rate for the EU 15 has increased by 4 percentage points to 91 per cent. 
Table 1 - Competition in fixed network and in mobile infrastructure, number of OECD countries

\begin{tabular}{cccccccc}
\hline & \multicolumn{3}{c}{ Competition in fixed network } & \multicolumn{5}{c}{ Competition in mobile infrastructure } \\
\hline & Monopoly & Duopoly & $\begin{array}{c}\text { Open } \\
\text { competition }\end{array}$ & Monopoly & Duopoly & $\begin{array}{c}\text { Three } \\
\text { operators }\end{array}$ & $\begin{array}{c}\text { Four or more } \\
\text { operators }\end{array}$ \\
\hline 1989 & 27 & 1 & 2 & 24 & 6 & 0 & 0 \\
1990 & 27 & 1 & 2 & 23 & 7 & 0 & 0 \\
1991 & 25 & 1 & 4 & 23 & 7 & 0 & 0 \\
1992 & 24 & 1 & 5 & 18 & 11 & 1 & 0 \\
1993 & 23 & 1 & 6 & 15 & 12 & 3 & 0 \\
1994 & 22 & 1 & 7 & 11 & 14 & 4 & 1 \\
1995 & 22 & 1 & 7 & 11 & 13 & 4 & 2 \\
1996 & 21 & 1 & 8 & 6 & 16 & 5 & 3 \\
1997 & 19 & 0 & 11 & 3 & 18 & 4 & 5 \\
1998 & 8 & 0 & 22 & 0 & 14 & 8 & 8 \\
1999 & 7 & 0 & 23 & 0 & 9 & 13 & 8 \\
2000 & 6 & 0 & 24 & 0 & 5 & 15 & 10 \\
2001 & 3 & 0 & 27 & 0 & 4 & 14 & 12 \\
2002 & 2 & 0 & 28 & 0 & 4 & 10 & 16 \\
2003 & 1 & 0 & 29 & 0 & 4 & 12 & 14 \\
2004 & 0 & 0 & 30 & 0 & 4 & 13 & 13 \\
\hline
\end{tabular}

Source: OECD (2005).

Interconnection is one of the basic building blocks for a competitive market. In the fixed sector the downward trend in interconnection tariffs has continued (see Figure 1), above all in the United Kingdom, for local level termination. Alongside, Estonia, Greece, Ireland, Italy and Sweden have performed significant cuts. Conversely, Malta and Slovakia have seen slight reductions and need more efforts to reach average EU levels. Finally, Latvia has introduced very significant cuts, bringing the rates for single and double transit to below the EU average. 
Figure 1 - EU15 fixed-to-fixed interconnection charges, weighted average

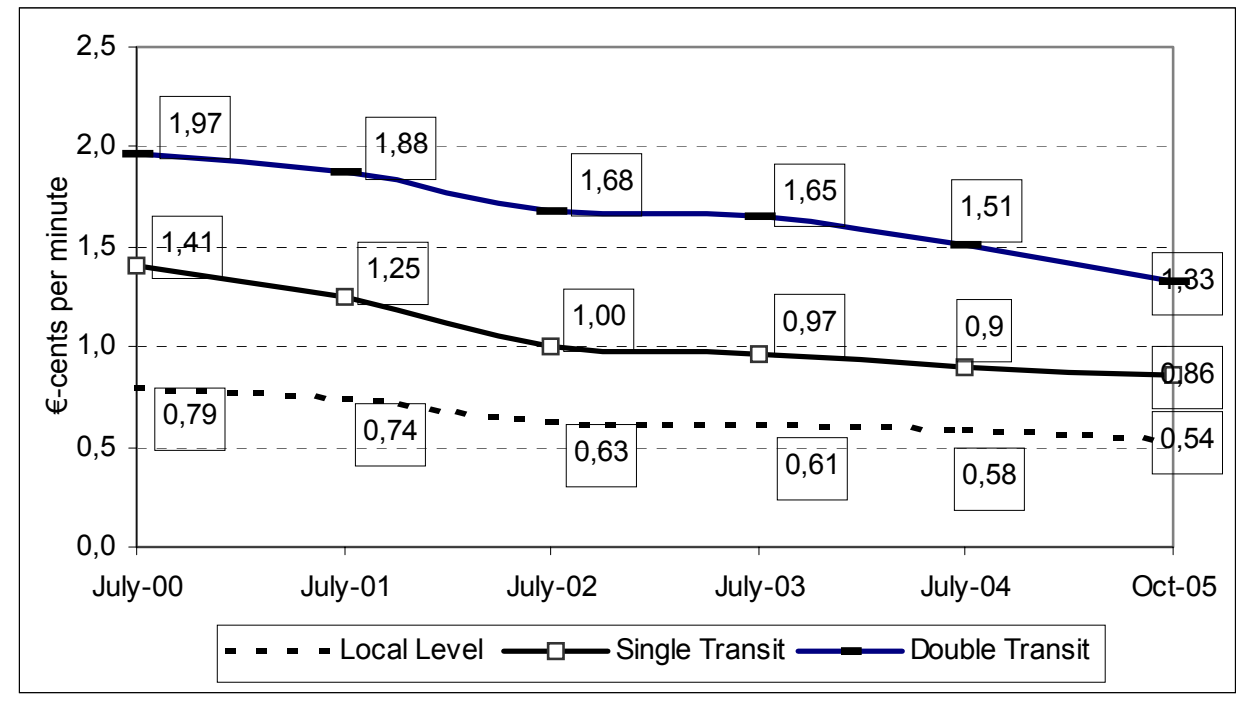

Source: EC (2006)

In the mobile sector, on the other hand, the average fixed-to-mobile termination rate for Significant Market Power (SMP) operators in the EU15 decreased by 14 per cent between July 2003 and July 2004. The divergence in charges between the SMP and non-SMP operators (see Figure 2) was mainly due to regulatory intervention by NRAs to orientate charges to cost for SMP operators, although even for non-SMP operators, interventions set by the NRAs have sometimes occurred ${ }^{3}$. Many Member States have implemented significant cuts, notably the United Kingdom, a reduction of more than 50 per cent, as well as Finland, Sweden and the Netherlands. Nevertheless, these charges are still eight times the equivalent rate (double transit) on the fixed network.

\footnotetext{
${ }^{3}$ For istance as a result of on the basis of a competition enquiry or setting a price ceiling to avoid excessive tariffs.
} 
Figure 2 - EU15 average fixed-to-mobile interconnecion charges for SMP and non-SMP operator in the national interconnection market

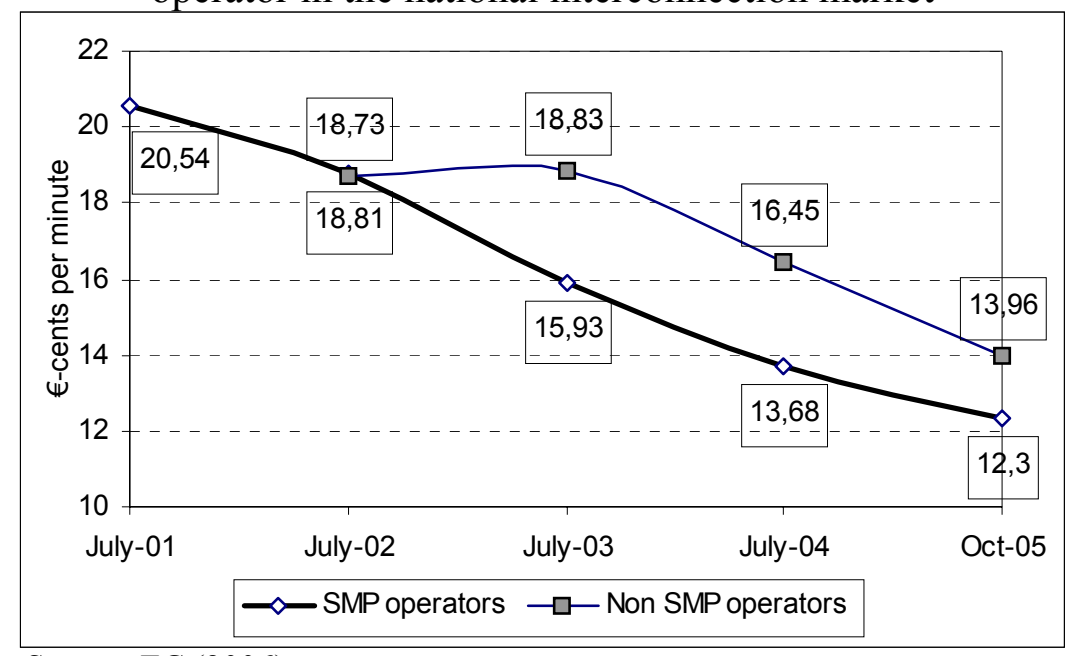

Source: EC (2006)

Overall, the conditions for competition seem to be well established in most OECD countries, and analogously, in the EU. The financial crisis, endured by the industry, has led to a number of mergers and bankruptcies among telecommunications operators. As a result, while the number of fixed Public Switched Telecommunication Network (PSTN) operators licensed in some countries has diminished, the number of new entrant operators has increased across most countries. ${ }^{4}$ However, despite the increase in the number of operators in the fixed telecommunications market, and that facilities-based competition is supported within OECD countries, competitive markets are developing slowly.

Regarding the EU Member States, to the best of our knowledge, so far all of them have concluded the adoption of primary legislation and notified the Commission thereof. As far as timely transposition is concerned, the Commission has launched legal proceedings against those States who were most behind in the process. As a result, proceedings are pending before the European Court of Justice against Belgium, France, Greece and

\footnotetext{
${ }^{4} 3 \mathrm{G}$ (IMT-2000) operators, for instance, are expected to rapidly increase over the time. One important development in OECD mobile markets is the growing number of mobile virtual network operators (MVNOs) in the market.
} 
Luxembourg. 5 Secondary legislation (substantive, in some cases) still needs to be implemented in five Member States in order for the primary legislation to be effective: Belgium, Estonia, France, Latvia and Poland.

\section{2 - Regulatory framework and study motivation}

Over the last decade, following Levy and Spiller (1994, 1996), scholars' attention has been focused on the effects of alternative institutional environments on the performance of capital intensive regulated industries such as telecommunications. Specifically, Levy and Spiller have argued that a country's institutional endowment determines "the nature of regulatory problems". ${ }^{6}$ In particular, subjective administrative discretion has a negative impact on the confidence of investors regarding the safeguard of their assets and, hence, on the performance of regulated industries. ${ }^{7}$

Moreover, empirical studies have shown that increasing investment and economies conditions are positively influenced by a good monitoring system across institutions (Henisz, 2000, 2002, and Henisz and Zelner, 2001). As a consequence, independent bodies have been created with the scope of ensuring a successful evolution towards competitive markets, regulating and watching over the relations between incumbents and new comers, who initially dependent on incumbents' services.

According to the WTO (1996), an independent regulator is defined as a regulator that is "separate from, and not accountable to, any supplier of basic telecommunications services". But this seems to be just a limited version of a wider meaning of independence of

\footnotetext{
${ }^{5}$ Belgium and Luxembourg both notified their transpositions measures in June 2005, while France notified their final secondary measures in September 2005.

${ }^{6}$ They give a wide definition of institutional endowment, moving from the study of the performance of regulated telecommunications industries in different political and social environments, but for a complete review on the importance of political institutions for economic performance see also North (1990), Thatcher (1999), Koelbe (1995) and Hall and Taylor (1996).

7 The authors underline the existence of a strong and independent judiciary; unified governments (as in parliamentary systems) or divided (as in many presidential systems); a turnover in government; and the quality of the regulatory bureaucracy.
} 
telecommunications regulatory institutions. Already in 1993, the International Telecommunications Union (ITU) has labeled independence as "a term that variously refers to the separation of regulatory and operational functions, neutrality, insulation from external pressure, or simply the designation of an official publicly identified as having the regulatory responsibility and not subservient to the rest of the ministry". Overall, there are three leading features of the independence of regulators: i) independence from the operators of the telecommunications sector; ii) independence from other interested parties such as industrial interests and iii) independence from political actors like ministers for the day-today matters (Smith, 1997).

Surveying countries' regulatory preferences in the telecommunications sector over the past years, it is possible to observe a variety of independent regulatory settings, whose two ends are the ministries and the National Regulatory Authorities. Within this continuum have occured several variations of regulatory institutions (Boylaud and Nicoletti, 2000; OECD, 2006) $)^{8}$. Undoubtly, it has taken place, in this field, an international trend towards organising regulatory authorities separate from the relevant ministry jurisdiction. In certain istances there were significant functional changes in responsibilities. As a result, the last available data reveal the presence of 132 such independent regulatory authorities worldwide, compared to 14 in 1990 (ITU, 2005).

Predictably, the valuable institutional settings for effective regulation, such as clearness of roles and aims of the regulator; independence of the regulator; participation in the regulatory process by interested parties; transparency of regulatory decisions; and accountability of the regulator for its decisions, have been also addressed from a theoretical perspective. For instance, Edwards and Waverman (2004) offer a systematic review of the topic.

\footnotetext{
${ }^{8}$ The OECD differentiates between independent regulator defined as "a sector specific independent regulator that is separate from the ministry as well as telecommunications operators, and a telecommunications regulator, which could either be the independent regulator or the ministry where there is no independent regulator" (OECD, 2000: 7).
} 
Nevertheless, as addressed by part of the juridical literature on the NRAs (Napolitano, 2005), we still assist at a dichotomic analysis of the performance provided by these entities. On the one hand, the juridical discipline discusses administrative performance, on the other hand the economic discipline addresses economic performance. Consequently, each of them develops autonomous indicators, without much effort to reconcile both outputs. Therefore, economic empirical evaluations are mainly based on incentive aspects; vice versa legal considerations are isolated to governance issues, without giving an overall view of the regulatory activity. In fact, the previous distinction can be reconducted to the regulatory governance and the regulatory incentive classification introduced by Levy and Spiller (1994, 1996) and later developed by other authors (Baldwin and Cave, 1999; La Spina and Majone, 2000; Oglietti and Pontarollo, 2003).

The main conclusion of such studies was the mutual acknowledgment that the Cost-Benefit Analysis has failed in assessing the regulatory effectiveness (Baldwin and Cave, 1999; La Spina and Majone, 2000). Particularly, three main limits of this approach have been outlined: a) there is an objective difficulty in identifying the real costs and benefits of regulatory activities; b) it is also possible that operators could adopt an opportunistic behaviour, hiding or manipulating the information, required for the assessing process; c) the complexity of the analysis could require the creation of ad hoc bureaucratic structure, that would imply a duplication of the regulatory costs, affecting consequently the assessing process itself (La Spina and Majone, 2000; Oglietti and Pontarollo, 2003).

For assessing the NRAs activity correctly, Baldwin and Cave (1999) have argued that one needs to identify clearly what is under the regulator control and what is not. The result is that we could take also into account in our evaluation analysis five benchmarks: the respect for legislative mandate, the accountability, the due process, the expertise and the efficiency. Accordingly, through these parameters it would be possible to be aware of NRAs' attitude. The determination of the legislative mandate, as it has been stated in the establishing law, help us in categorizing in which kind of regulatory governance, NRAs operate. As a result, we should be aware of the trade-off the Authorities have to face between the discretion and 
the rules they are asked to follow. This is equivalent to address what are their competencies and conversely, their responsibilities within the regulatory decision-making process. It is quite intuitive that the higher the level of transparency adopted by the authorities, the lower the degree of discretion, and consequently the lower the degree of uncertainty for the private operators, who are so more spurred in investing in the sector.

Unsurprisingly, few studies have focused on the empirical assessment of NRAs. This lack of attention was partially due to the fact that in most EU Member States, those authorities have been established recently and, thus, qualitative and quantitative data on those institutions are still poor. Such analysis focus on how capturing regulatory independence, using simple dummy variables to identify if the regulatory agency is or not directly under the control of the ministry (Edwards and Waverman, 2004). ${ }^{9}$

Gilardi (2005) has argued that Independent Regulatory Authority (IRAs) can be evaluated by looking at i) their impact on performance on the markets they regulate and capacity to strike a balance between possibly conflicting goals, ii) their capacity to produce high quality regulation and iii) the extent to which they respect the accountability standards. According to the author, the first and second aims can be measured through an econometric analysis assessing the link between IRAs and a range of indicators of market performance (defined widely to include the interests of both firms and consumers) and regulatory quality, while the third needs an assessment on a case-by-case basis.

Our study innovates on prior empirical works on regulatory governance since we examine the NRAs considering the features discussed above, and assessing efficiency and effectiveness in NRAs using a non-parametric analysis.

\footnotetext{
${ }^{9}$ For a detailed overview of this literature see Stern and Cubbin (2003), Gual and Trillas (2004) and Edwards and Waverman (2004). Regarding Italy, Abate and CIò (2000) investigated the energy sector, while Oglietti and Pontarollo (2000) studied the Italian Regulatory Authority for Telecomunication.
} 


\section{3 - Analytical framework}

We use Data Envelopment Analysis in order to compute input and output technical efficiency measures. The purpose of an input-oriented study is to evaluate by how much input quantity can be proportionally reduced without changing the output quantities. Alternatively, by computing output-oriented measures, one could also try to assess how much output quantities can be proportionally increased without changing the input quantities used. Since the computation of efficiency scores in the DEA framework uses linear programming, which is not subject to statistical problems such as simultaneous equation bias and specification errors, both output and input-oriented models will identify the same set of efficient/inefficient producers or Decision Making Units (DMUs), in our case the NRAs. ${ }^{10}$

Using a simple example, assume that three different hypothetical NRAs display the following values for the output indicator and the input level, as reported in Table 2.

\begin{tabular}{lcc}
\multicolumn{3}{c}{ Table $2-$ Values for NRAs A, B and C } \\
\hline & Output indicator & Input level \\
\hline NRA A & 65 & 800 \\
NRA B & 68 & 1150 \\
NRA C & 75 & 1000 \\
\hline
\end{tabular}

The input level is the lowest in the case of the NRA A, which also reports the lowest output level. For instance, NRA C attains the highest output level even though it does not use the highest input level. NRA B may be considered inefficient, since it performs worse than the NRA C. In other words, the NRA B is dominated by the NRA C.

The use of DEA allows the determination of a theoretical production possibility frontier and the computation of efficiency scores for each NRA. We compute those efficiency

\footnotetext{
${ }^{10}$ Data Envelopment Analysis, originated from Farrell (1957) seminal work and was popularised by Charnes, Cooper and Rhodes (1978). Coelli et al. (2002), and Thanassoulis (2001) offer good introductions to the DEA methodology.
} 
scores in such a way that they will be below unity if the DMU is inefficient and have the value one if the DMU is on the frontier (i.e. it is efficient).

\section{4 - Efficiency analysis}

We assess in this section the performance of National Regulatory Authorities across 16 EU countries: Austria, Belgium, Czech Republic, Denmark, France, Germany, Greece, Hungary, Ireland, Italy, the Netherlands, Poland, Portugal, Spain, Sweden, and the United Kingdom. As inputs we use both the number NRAs' employees and their revenues, scaled in per capita terms for each country. Particularly, we use the data provided by each NRA in its Annual Report for the year 2004. Regarding the output measure we first construct a composite indicator that tries to take into account the effective economic regulation in the telecommunications sector. The next subsection discusses and explains the construction of such composite output measure, while subsection 4.2 reports and analysis the DEA results.

\section{1 - Composite Regulatory Performance Indicator (CRPI)}

In this subsection we construct our measure of performance for NRAs in providing effective economic regulation in the telecommunications sector, by computing the so-called Composite Regulatory Performance Indicator (CRPI).

For computing the CRPI we use two different databases: one is reported in the SCORECARD Annual Report, published by the European Competitive Telecommunications Association (ECTA), the other is the European Union Regulatory Institutions (EURI) Database developed by the Regulation Initiative Research Group at the

London Business School. This allows us to trace some considerations on the existing methodology already implied in assessing the NRAs performance. Such composite indicators, CRPIsc and CRPIeuri, can be used as an output in the non-parametric approach DEA, in order to compute efficiency scores for NRAs in 2005. 
The composite indicator based on the ECTA data is a simple average of a set of subindicators of regulatory performance, grouped in four main leading regulatory aspects: the effectiveness of the national regulatory system; the effectiveness of the dispute settlement body; general market access conditions; and application of remedies in markets for narrowband voice, mobile, broadband and business service.

According to the ECTA description, the chosen areas intend to reproduce the main principles expressed in the WTO Reference Paper on Telecommunications (1996), to which the European Union has adhered to and that strengthens the regulatory regimes.

In particular, the first two areas of assessment deal with the regulator and the dispute settlement body, in terms of their modus operandi and effectiveness, considering the speed of process, fairness and enforcement power. Specifically, as effectiveness of regulation is generally meant the degree to which Member States and regulators have implemented and applied the new regulatory framework.

Consequently, effectiveness of the regulator in relation to the exercise of its general powers is, essentially, a function of its: (i) speed of process, (ii) transparency of activities, (iii) powers and effectiveness of sanctions, (iv) scale of resources; (v) effectiveness of the appeal procedure; (vi) degree of independence; and (vii) speed and accuracy of the market analysis procedure.

Following the WTO Reference Paper cited above, the ECTA survey treats separately the role of the dispute settlement body and the new NRAs' functions, which result from the new regulatory framework. NRAs are, in fact, now required to undertake a forceful market analyses, in accordance with the European Commission's guidelines. Additionally, their public accountability in their decision-making process is increasing as in the case of public consultation process. As a result, the assessment of the efficiency of the dispute settlement body is based on criteria similar to those used to evaluate NRAs' general powers, together 
with their: (i) speed in exercising their powers, (ii) respect for due process rules, (iii) effectiveness of sanctions and (iv) effectiveness of appeal procedure.

The third area touches how access rules and regulations are applied, i.e. the general market access conditions. To facilitate all competitors in providing services and giving more choices and assortment to end-users, regulators need to have broad policies to allow the provision of access in those markets, where some operators have Significant Market Power (SMP). ${ }^{11}$ To estimate the application of such access rules, ECTA has considered the typical access remedies illustrated in the new regulatory framework: (i) access obligations; (ii) non discrimination and margin squeeze; (iii) price control; (iv) cost accounting separation; (v) rights of way; and (vi) numbering.

The fourth area outlines the application of regulations and the degree of competition in key markets. This is measured through assessing the accessibility of wholesale products, which are widely recognised as playing an important role in ensuring competitive markets, and the measurement of market outcomes such as market shares, take-up of products, and end-user prices. The services covered include: (i) narrow band voice services, (ii) mobile services, (iii) access services relevant to business customers, and (iv) broadband services.

Figure 3 shows the composition of the overall CRPI measure, illustrating how we derive these performance indicators, based on the 21 sub-indicators of regulatory effectiveness and access to markets and products.

\footnotetext{
${ }^{11}$ Quite often, new operators do not have direct physical connections to end-users. Therefore, they depend substantially on their ability to benefit from rights of way enabling them to build or share physical infrastructure (since duplication of existing access networks is not economically feasible), and to have access to suitable numbering ranges.
} 


\section{Figure 3 -Composite Regulatory Performance Indicator Scorecard (CPRIsc)}

Transparency

Independence of regulator

Speed of process

Powers and sanctions

Scale of resources

Compliance with market analysis requirements and imposition of remedies

Effectiveness of appeal process

Speed of dispute process

Due process

Effectiveness of sanctions

Effectiveness of appeal process

Access obligations

Non discrimination and price squeeze

Price control

Accounting separation

Rights of way and facility sharing

Numbering

Mobile

Business

Narrow Band Voice

Broadband

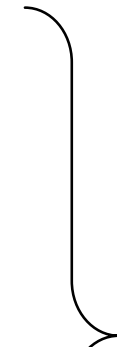

Effectiveness of the national

regulatory system (I1)

Effectiveness of the dispute settlement body (I2)

General market access conditions (I3)

Access to products (I3) 
In order to facilitate the compilation, we normalised the values and set the average for all indices equal to unity (following an approach inspired on Afonso et al., 2005). The values for each NRA are then recalculated relative to the average. We compile the performance indicator from the various indices giving equal weight to each of them. This weighing up of the variables is quite straightforward and economically intuitive (even though it is still somewhat ad hoc), and it avoids the problem of lack of economic justification.

Table 3 presents the results for the constructed CRPIsc for the year 2005, using the ECTA data. $^{12}$

Table 3 - NRAs’ Composite Regulatory Performance Indicator Scorecard, 2005

\begin{tabular}{lccccc}
\hline & $\begin{array}{c}\text { Effectiveness of } \\
\text { the national } \\
\text { regulatory system }\end{array}$ & $\begin{array}{c}\text { Effectiveness of } \\
\text { the dispute } \\
\text { settlement body }\end{array}$ & $\begin{array}{c}\text { General market } \\
\text { access conditions }\end{array}$ & $\begin{array}{c}\text { Access to } \\
\text { products }\end{array}$ & CPRIsc \\
\hline Austria & 1.21 & 0.93 & 1.18 & 1.27 & 1.15 \\
Belgium & 0.68 & 1.16 & 0.94 & 0.97 & 0.94 \\
Czech Republic & 0.85 & 0.81 & 0.64 & 0.81 & 0.78 \\
Denmark & 1.13 & 1.34 & 1.35 & 1.51 & 1.33 \\
France & 1.17 & 1.22 & 0.87 & 1.23 & 1.12 \\
Germany & 0.64 & 1.05 & 1.02 & 0.56 & 0.82 \\
Greece & 0.86 & 0.90 & 0.59 & 0.84 & 0.80 \\
Hungary & 1.09 & 0.94 & 0.68 & 0.93 & 0.91 \\
Ireland & 1.07 & 0.93 & 1.39 & 1.01 & 1.10 \\
Italy & 1.01 & 0.79 & 1.12 & 0.83 & 0.94 \\
Netherlands & 0.87 & 1.05 & 1.27 & 0.82 & 1.00 \\
Poland & 0.90 & 0.71 & 0.62 & 0.78 & 0.75 \\
Portugal & 1.17 & 1.20 & 0.88 & 1.07 & 1.08 \\
Spain & 0.92 & 0.99 & 0.81 & 0.83 & 0.89 \\
Sweden & 1.13 & 0.70 & 0.98 & 0.87 & 0.92 \\
UK & 1.29 & 1.31 & 1.75 & 1.44 & 1.45 \\
\hline Mean & 1.00 & 1.00 & 1.00 & 1.00 & 1.00 \\
Maximum & 1.29 & 1.34 & 1.75 & 1.51 & 1.45 \\
Minimum & 0.64 & 0.70 & 0.59 & 0.56 & 0.75 \\
\hline & & & & &
\end{tabular}

Overall, the best performers seem to be United Kingdom, Denmark, and Austria, while Poland, the Czech Republic and Greece are placed at lower end. Indeed, the UK scores the

\footnotetext{
${ }^{12}$ The data and the respective sources are provided in the Annex.
} 
maximum index level for two of the four sub-indicators (effectiveness of the national regulatory system, and general market access conditions), while Denmark scores the maximum on the other two sub-indicators (effectiveness of the dispute settlement body, and access to products).

Regarding the Composite Regulatory Performance Indicator EURI, CPRIeuri, this is based on the simple average of two sub-indicators that measure respectively regulatory independence (EURI-I) and regulatory quality (EURI-Q).

Specifically, the EURI Independence (EURI-I) index is a simple sum of 12 formal institutional elements in the regulation of telecommunications in the EU, which are directly correlated to the independence of the NRA from the government. Since it was attributed equal weight to each element, the index can therefore range from 0 to 12 .

In detail (see Edwards and Waverman, 2004), the EURI components take into account: 1) whether the NRA is single or multi-sector (multi-sector); 2) whether the NRA is single or multi-member (multi-member); 3) whether the NRA is funded by government appropriations or industry fees and consumer levies (funding); 4) whether the NRA reports only to the executive government or also to the legislature (reporting); 5) whether the NRA has adequate powers regarding interconnection issues (interconnect powers); 6) whether the NRA shares its regulatory functions with the executive (shared roles); 7) whether the legislature is involved in NRA member appointments (legislative appointment); 8) whether NRA member terms of appointment are fixed (fixed terms); 9) whether NRA member terms are renewable (renewable terms); 10) and 11) whether NRA resources are adequate (staff and budget); and 12) whether the NRA has been in operation for at least two years (experience). Each element is measured as either a categorical or dummy variable on a zero to one scale. 
The EURI Regulatory Quality (EURI-Q) index instead, is the sum of 5 elements identifying on overall regulatory quality (aside from independence): clarity of roles (s), NRA powers index (zero to one), enforcement powers (s), effective appeals(s) and effective licensing (s).

Table 4 shows the composition of the overall CRPI measure and Table 5 reports the normalised data for the two sub-indicators for 2003.

Table 4 - Composite Regulatory Performance Indicator EURI (CPRIeuri)

\begin{tabular}{|c|c|}
\hline Regulatory Independence (EURI-I) & Regulatory Quality (EURI \\
\hline 1. NRA Characteristics & 1. Clarity of regulatory roles \\
\hline - Multi-sector & \\
\hline - Multi-member & 2. NRA Powers \\
\hline - Funding & - Licensing \\
\hline - Reporting & - Tariffs \\
\hline - Interconnect power(s) & - Interconnection (s) \\
\hline - Shared roles & \\
\hline & 3. Effective Enforcement Pov \\
\hline $\begin{array}{l}\text { 2. NRA Member Appointments and Terms of } \\
\text { Office }\end{array}$ & \\
\hline $\begin{array}{l}\text { - Legislative appointment } \\
\text { - Fixed terms }\end{array}$ & 4. Effective Appeals Process \\
\hline - Renewable terms & 5. Effective Licensing \\
\hline $\begin{array}{l}\text { 3. NRA Resources } \\
\text { - Staff } \\
\text { - Budget }\end{array}$ & \\
\hline 4. NRA Experience & \\
\hline
\end{tabular}

According to Edwards and Waverman (2004), EURI index is positively correlated with other but similarly intentioned, measures of regulatory independence in the EU member states. In particular, in their analysis, these authors outline the correlation with Gual and Trillas' (2003) measure of regulatory independence, and with subjective assessments of the degree of independence of the regulator from government, as reported in the European Commission Reports on the Implementation of the Telecommunications Regulatory Framework (1998 - 2003). Finally, they found that the EURI indicator is also positively 
correlated with the ECTA (2004) measure of regulatory independence in 10 EU member states. $^{13}$

Albeit this last result was the reason that has driven also our choice to use the two indicators, we see that the correlation between the CRPIsc and the CRPIeuri is not that high (only 22 per cent).

Table 5 - NRAs' Composite Regulatory Performance Indicator EURI, 2003

\begin{tabular}{lccc}
\hline & $\begin{array}{c}\text { Regulatory } \\
\text { independence } \\
\text { (EURI-I) }\end{array}$ & $\begin{array}{c}\text { Regulatory } \\
\text { quality } \\
\text { (EURI-Q) }\end{array}$ & CPRIeuri \\
\hline Austria & 0.69 & 0.93 & 0.81 \\
Belgium & 0.62 & 0.93 & 0.77 \\
Denmark & 0.79 & 1.55 & 1.17 \\
France & 0.89 & 0.72 & 0.81 \\
Germany & 1.10 & 0.83 & 0.96 \\
Greece & 1.03 & 0.93 & 0.98 \\
Ireland & 1.17 & 1.24 & 1.20 \\
Italy & 1.41 & 0.21 & 0.81 \\
Netherlands & 1.07 & 1.24 & 1.15 \\
Portugal & 1.31 & 1.24 & 1.27 \\
Spain & 0.93 & 0.52 & 0.72 \\
Sweden & 1.20 & 1.24 & 1.22 \\
UK & 0.79 & 1.44 & 1.12 \\
\hline Mean & 1.00 & 1.00 & 1.00 \\
Maximum & 1.41 & 1.55 & 1.27 \\
Minimum & 0.62 & 0.21 & 0.72 \\
\hline
\end{tabular}

As shown in Table 5, overall the best performers seem to be Portugal, Sweden, Ireland and Denmark, while Spain, Belgium, Italy and France are placed at lower end. Italy scores the maximum index level for EURI-I (Regulatory Independence), while Denmark scores the maximum for EURI-Q (Regulatory Quality). It seems that in this case the analysis is able to catch mostly the regulatory governance aspects, but not the NRAs' impact on the markets they regulate. In this last feature the ECTA Scorecard seems to be broader and more

\footnotetext{
${ }^{13}$ Excluding from the ECTA measure the information on government ownership of the PTO, as they do not consider this to be a component of regulatory independence.
} 
adequate for our investigation, although not exhaustive. Nevertheless, we will also use the EURI indicator in the DEA computations for completeness sake. Therefore, the derived CRPI indicators will be used ahead in the next sub-section as to base our output measures for the DEA analysis.

\section{2 - Efficiency results}

Performance in itself, as measured in the previous section, may be achieved with a different combination of resources, which is precisely what we will now try to assess when looking at efficiency.

Since the number of DMUs is not very large, one has to be careful in not using too many inputs or outputs, which would then increase the number of efficient by default DMUs. ${ }^{14}$ For our DEA analysis, we use two input measures: a financial measure, $X 1$, which is the overall amount of revenues for each NRA, and a quantitative measure, $X 2$, the number of employees for every NRA defined as follows (data and sources are reported in the Annex):

$X 1$ - financial resources of the NRA in per capita terms vis-à-vis the population of the country, euros in PPP;

$X 2$ - the number of NRA employees per 1000 inhabitants.

The general relationship for the theoretical production possibility frontier that we expect to test, regarding efficiency in regulation, can be given by the following function for NRA $i$ :

$$
Y_{i}=f\left(X 1_{i}, X 2_{i}\right), i=1, \ldots, n
$$

where $Y_{i}$ is the CRPI, and $X 1_{i}$ and $X 2_{i}$ are the previously defined two inputs for each NRA.

\footnotetext{
${ }^{14}$ With less than three DMUs per input and output there is the risk that too many DMUs will turn out to be efficient.
} 
In order to go around the eventual difficulties posed to the DEA approach when there are a significant number of inputs and/or outputs, we used principal component analysis (PCA) to aggregate some of the sub-indicators and reduce the dimensionality of multivariate data.

The idea of the PCA is to describe the variation of a multivariate data set through linear combinations of the original variables (see, for instance, Everitt and Dunn, 1991). Generally, we are interested in seeing if the first few components portray most of the variation of the original data set, for instance, 80 per cent, without much loss of information. In a nutshell, the principal components are uncorrelated linear combinations of the original variables, which are then ranked by their variances in descending order. This provides a more parsimonious representation of the data set and avoids, for instance, that in the DEA computations too many DMUs are labelled efficient by default.

Usually one applies the PCA by imposing that the original variables are normalized to have zero mean, this means that the computed principal components scores also have zero mean, and therefore some of the results from the PCA can be negative. Since, DEA inputs and outputs need to be strictly positive, the PCA results will be increased by the most negative value, plus one, in order to ensure strictly positive data (see, for instance, Adler and Golany, 2001).

Regarding the output information based on the CRPIsc data, we first use the more disaggregated information of the four sub-indicators via a principal component analysis. The results of such analysis (see Table 6) that led us to use the first two principal components as the two output measures, which explain around 85 per cent of the volatility of the four sub-indicators in the CRPIsc (first four columns in Table 3). Moreover, this also implies that we only take into account the components whose associated eigenvalues are above 0.7 , a rule suggested by Jollife (1972). 
Table 6 - Principal component analysis for the 4 sub-indicators of CRPIsc

\begin{tabular}{ccc}
\hline Component & Eigenvalue & Cumulative R-Squared \\
\hline 1 & 2.6035909 & 0.6508977 \\
2 & 0.7775812 & 0.8452930 \\
3 & 0.5142657 & 0.9738594 \\
4 & 0.1045623 & 1.0000000 \\
\hline
\end{tabular}

Additionally, we report in Table 7 the abovementioned principal components, to be used in the subsequent section in the DEA computations.

Table 7 - Principal components of the CRPIsc sub-indicators, used in the DEA

\begin{tabular}{lcc}
\hline & P1 & P2 \\
\hline Austria & 2.975 & 4.128 \\
Belgium & 1.854 & 1.060 \\
Czech Republic & 1.124 & 3.199 \\
Denmark & 3.917 & 2.243 \\
France & 3.000 & 3.087 \\
Germany & 1.131 & 1.000 \\
Greece & 1.258 & 2.944 \\
Hungary & 1.883 & 3.763 \\
Ireland & 2.589 & 3.236 \\
Italy & 1.795 & 3.635 \\
Netherlands & 2.083 & 1.928 \\
Poland & 1.000 & 3.779 \\
Portugal & 2.748 & 3.077 \\
Spain & 1.658 & 2.704 \\
Sweden & 1.790 & 4.555 \\
United Kingdom & 4.406 & 2.706 \\
\hline
\end{tabular}

Note: The original principal components data were increased by the most negative value plus one, in order to ensure strictly positive data.

In Table 8 we report the DEA analysis results obtained with the two inputs, $X 1$ and $X 2$, and two outputs, the abovementioned first two principal components. 
Table 8 - DEA results for NRAs, 2004, 2 inputs (financial resources, employees) and 2 outputs (first two principal components of the four sub-indicators in CRPIsc)

\begin{tabular}{lccccccc}
\hline \multirow{2}{*}{ Country } & \multicolumn{2}{c}{ Input oriented } & \multicolumn{2}{c}{ Output oriented } & & Peers \\
& VRS TE & Rank & VRS TE & Rank & CRS TE \\
\cline { 2 - 5 } Austria & 1.000 & 1 & 1.000 & 1 & Austria/ Austria & 0.240 \\
Belgium & 0.117 & 13 & 0.421 & 15 & France, Poland/ UK & 0.073 \\
Czech Republic & 0.108 & 14 & 0.796 & 11 & Italy, France/ Sweden, Hungary & 0.108 \\
Denmark & 0.212 & 11 & 0.889 & 8 & France, UK/ UK & 0.072 \\
France & 1.000 & 1 & 1.000 & 1 & France/ France & 1.000 \\
Germany & 0.367 & 9 & 0.331 & 16 & France/ France, Austria, UK & 0.138 \\
& & & & & Poland, France/ Sweden, Hungary, & \\
Greece & 0.203 & 12 & 0.757 & 13 & Italy & 0.191 \\
Hungary & 1.000 & 1 & 1.000 & 1 & Hungary/ Hungary & 0.430 \\
Ireland & 0.091 & 15 & 0.820 & 9 & Poland, Italy, France/ UK, Austria & 0.084 \\
Italy & 1.000 & 1 & 1.000 & 1 & Italy/ Italy & 1.000 \\
Netherlands & 0.272 & 10 & 0.618 & 14 & France, Poland/ France, Austria, UK & 0.189 \\
Poland & 1.000 & 1 & 1.000 & 1 & Poland/Poland & 1.000 \\
Portugal & 0.062 & 16 & 0.820 & 10 & France, Poland/ Austria, UK & 0.062 \\
& & & & & Poland, France/ France, Austria, & \\
Spain & 0.703 & 8 & 0.778 & 12 & Poland, Italy & 0.609 \\
Sweden & 1.000 & 1 & 1.000 & 1 & Sweden/ Sweden & 0.119 \\
United Kingdom & 1.000 & 1 & 1.000 & 1 & UK/ UK & 0.294 \\
\hline Average & 0.571 & & 0.827 & & & 0.350 \\
\hline
\end{tabular}

Notes: CRS TE - constant returns to scale technical efficiency. VRS TE - variable returns to scale technical efficiency.

According to the results from Table 8, the theoretical production possibility frontier has seven countries: Austria, France, Hungary, Italy, Poland, Sweden and the United Kingdom. This means that more than half of the DMUs would be seen as performing in an efficient way. However, given the relatively small number of DMUs in our sample, one could reduce the number of inputs or outputs in order to avoid that too many DMUs are labelled efficient, since some of them are simply efficient by default. Indeed, one can notice that this is precisely the case of Austria, Hungary, and Sweden.

Therefore, one can use as an alternatively the overall CRPIsc measure as a single output (the last column in Table 3), and the results of such approach are reported in Table 9. 
Table 9 - DEA results for NRAs, 2004, 2 inputs (financial resources, employees) and 1 output (CRPIsc)

\begin{tabular}{lccccccc}
\hline \multirow{2}{*}{ Country } & \multicolumn{2}{c}{ Input oriented } & \multicolumn{2}{c}{ Output oriented } & & Peers \\
& VRS TE & Rank & VRS TE & Rank & & CRS TE \\
\hline Austria & 0.275 & 8 & 0.865 & 5 & France, UK/ France, UK & 0.209 \\
Belgium & 0.117 & 12 & 0.615 & 13 & France, Poland/ UK & 0.098 \\
Czech Republic & 0.104 & 13 & 0.530 & 16 & France / UK & 0.072 \\
Denmark & 0.208 & 10 & 0.891 & 4 & France, UK/ UK & 0.063 \\
France & 1.000 & 1 & 1.000 & 1 & France/ France & 1.000 \\
Germany & 0.367 & 6 & 0.599 & 14 & France/ France, UK & 0.267 \\
Greece & 0.203 & 11 & 0.552 & 15 & France, Poland/ France, UK & 0.148 \\
Hungary & 0.354 & 7 & 0.739 & 11 & France/ France, UK & 0.287 \\
Ireland & 0.081 & 15 & 0.776 & 8 & France, Poland/ France, UK & 0.080 \\
Italy & 0.853 & 4 & 0.817 & 6 & France/ UK & 0.710 \\
Netherlands & 0.272 & 9 & 0.743 & 9 & France, Poland/ France, UK & 0.243 \\
Poland & 1.000 & 1 & 1.000 & 1 & Poland/ Poland & 1.000 \\
Portugal & 0.062 & 16 & 0.743 & 10 & France, Poland/ UK & 0.060 \\
Spain & 0.703 & 5 & 0.781 & 7 & France, Poland/ France, UK & 0.563 \\
Sweden & 0.083 & 14 & 0.688 & 12 & France, Poland/ France, UK & 0.071 \\
United Kingdom & 1.000 & 1 & 1.000 & 1 & UK/ UK & 0.258 \\
\hline Average & 0.418 & & 0.772 & & & 0.320 \\
\hline
\end{tabular}

Notes: CRS TE - constant returns to scale technical efficiency. VRS TE - variable returns to scale technical efficiency.

From the results in Table 9 it is possible to see that three countries are now on the theoretical production possibility frontier: France, Poland and the United Kingdom. Morevoer, the three countries that previously were efficient by default (Austria, Hungary, and Sweden) are no longer on the frontier.

In Table 10 we report the DEA analysis results obtained with the two inputs, $X 1$ and $X 2$, and the abovementioned overall CRPIeuri measure as a single output. In this case, where the sample is smaller, the theoretical production possibility frontier has just three countries: France, Netherlands and Portugal. 
Table 10 - DEA results for NRAs, 2004, 2 inputs (revenues, employees) and 1 output (CRPIeuri)

\begin{tabular}{|c|c|c|c|c|c|c|}
\hline \multirow[t]{2}{*}{ Country } & \multicolumn{2}{|c|}{ Input oriented } & \multicolumn{2}{|c|}{ Output oriented } & \multirow{2}{*}{$\begin{array}{c}\text { Peers } \\
\text { Input/output }\end{array}$} & \multirow[t]{2}{*}{ CRS TE } \\
\hline & VRS TE & Rank & VRS TE & Rank & & \\
\hline Austria & 0.213 & 12 & 0.695 & 12 & France/ Netherlands, Portugal & 0.213 \\
\hline Belgium & 0.118 & 13 & 0.646 & 13 & France/ Portugal, Netherlands & 0.113 \\
\hline Denmark & 0.298 & 11 & 0.919 & 9 & Netherlands, Portugal / Portugal & 0.079 \\
\hline France & 1.000 & 1 & 1.000 & 1 & $\begin{array}{l}\text { France/ France } \\
\text { Netherlands France/ Netherlands }\end{array}$ & 1.000 \\
\hline Germany & 0.830 & 6 & 0.944 & 8 & $\begin{array}{l}\text { France } \\
\text { Netherlands, France/ Portugal, }\end{array}$ & 0.438 \\
\hline Greece & 0.491 & 10 & 0.843 & 10 & $\begin{array}{c}\text { Netherlands } \\
\text { Portugal, Netherlands / Netherlands, }\end{array}$ & 0.255 \\
\hline Ireland & 0.745 & 7 & 0.976 & 5 & Portugal & 0.122 \\
\hline Italy & 0.853 & 5 & 0.974 & 6 & France/ Netherlands, France & 0.853 \\
\hline Netherlands & 1.000 & 1 & 1.000 & 1 & Netherlands/ Netherlands & 0.389 \\
\hline Portugal & 1.000 & 1 & 1.000 & 1 & Portugal/ Portugal & 0.098 \\
\hline Spain & 0.720 & 8 & 0.841 & 11 & $\begin{array}{l}\text { France/ Netherlands, France } \\
\text { Portugal, Netherlands / Netherlands, }\end{array}$ & 0.643 \\
\hline Sweden & 0.959 & 4 & $\begin{array}{l}0.996 \\
0.961\end{array}$ & 4 & $\begin{array}{c}\text { Portugal } \\
\text { Netherlands, France/ Netherlands, }\end{array}$ & 0.134 \\
\hline United Kingdom & 0.704 & 9 & & 7 & Portugal & 0.277 \\
\hline Average & 0.687 & & 0.907 & & & 0.355 \\
\hline
\end{tabular}

Notes: CRS TE - constant returns to scale technical efficiency.

VRS TE - variable returns to scale technical efficiency.

As in the case of the computation of the CRPI, we can observe results that are quite distant from the ones obtained using the CRPIsc. It seems to be significant the case of Portugal that previously was ranked in the lowest positions, and now it is one of the best performer. Conversely, France seems to confirm its position on the frontier. On the other hand, the UK is now ranked in a lower position.

\section{5 - Conclusion}

In this paper, we have evaluated the performance of National Regulatory Authorities (NRAs) across $16 \mathrm{EU}$ countries regarding the effective economic regulation in telecommunications sector. For that purpose we construct a so-called Composite Regulatory Performance Indicator (CRPI), which is our output measure, against the inputs used: the number of NRAs' employees and their revenues, scaled in per capita terms for 
each country. With data for 2004, we constructed the performance index as a composite index of four sub-indicators of NRAs' performance in leading regulatory aspects such as: effectiveness of the national regulatory system, effectiveness of the dispute settlement body, general market access conditions and application of remedies in markets for narrowband voice, mobile, broadband and business services.

We computed input and output efficiency scores by solving a standard DEA problem with the NRAs as DMUs. The results indicate that inefficiencies may be significant, and some improvements may be possible across countries in order for them to move closer to the theoretical production possibility frontier. On average, and using one output and two input analysis, NRAs could have increased their output by 22.8 percent using the same resources, with a NRA like the Greek one having a theoretical margin for potential output improvement of 44.8 percent. On the other hand, on average, NRAs could have decreased their inputs by 58.2 percent and still obtain the same output. Nevertheless, the fact that some NRAs are not located on the theoretical production possibility frontier, and not labelled efficient, does not mean that they could actually be on the frontier. For instance, regulators may simply favour the faster implementation of a different set of regulatory interventions.

To our knowledge, this is the first attempt at computing a performance composite indicator for evaluating NRAs performance and the subsequent non-parametric analysis. However, the reported results have to be seen as indicative and need to be interpreted with some care. Indeed, environmental or non-discretionary factors may play a role in determining performance levels and efficiency. 


\section{Appendix}

Table A1 - European Regulatory Framework for the Telecommunications Sector

\begin{tabular}{|c|c|}
\hline Directives & Regulatory Governance \\
\hline $\begin{array}{l}\text { Framework Directive } \\
\text { Directive 2002/21/EC of the European Parliament and of } \\
\text { the Council of } 7 \text { March } 2002 \text { on a common regulatory } \\
\text { framework for electronic communications networks and } \\
\text { services; (OJ L108/33, 24.4.2002) }\end{array}$ & $\begin{array}{l}\text { It regulates the principles that concern all the activities enclosed in the other specific directives, which constitute the new regulatory } \\
\text { framework. It focuses above all on the responsibilities and powers of the National Regulatory Authorities, since they are the basis of } \\
\text { the new regulatory system. Specifically, the objectives for NRA's action defined at EU level should be entirely reproduced in } \\
\text { national laws, as should the condition that NRAs work autonomously from operators and neutrally. The complete series of powers } \\
\text { attributed to NRAs, in force of the new framework, must also be attributed to them through national law. It is also crucial that the } \\
\text { various responsibilities ascribed to NRAs should be clearly recognizable, so that operators and users know whom to address for any } \\
\text { particular problem. Moreover, Member States must guarantee effective mechanisms for appeal and dispute resolution, and } \\
\text { transposition laws should warrant the suitable completion of the implementation process, mainly the NRAs' first market reviews On } \\
\text { the other hand, National legislation should supply transparency to the sector by making certain that the requests of the framework } \\
\text { regarding the public provision of significant information on the market and its regulatory settings are fulfilled }\end{array}$ \\
\hline $\begin{array}{l}\text { Access Directive } \\
\text { Directive 2002/19/EC of the European Parliament and of } \\
\text { the Council of } 7 \text { March } 2002 \text { on access to, and } \\
\text { interconnection of, electronic communications networks } \\
\text { and associated facilities; (OJ L108/7, 24.4.2002) }\end{array}$ & $\begin{array}{l}\text { It delineates the values that should drive the NRAs in applying their powers to supervise and, where necessary, regulate relations } \\
\text { between the operators, i.e. the wholesale market. Access and interconnection conditions should be mostly ruled by commercial } \\
\text { negotiations, but the NRAs shall still have authority to intervene so that the policy purposes are met. Therefore, NRAs necessitate } \\
\text { justifying their decisions to commit market players and the market analysis procedures stated by the new framework offer the means } \\
\text { by which they are asked to act. As a result, NRAs benefit from a broad grade of discretion that must be reconciled with the actions } \\
\text { of the Commission and the NRAs of other Member States so as to guarantee the application of the regulatory principles across the } \\
\text { EU. }\end{array}$ \\
\hline $\begin{array}{l}\text { Directive 2002/20/EC of the European Parliament and of } \\
\text { the Council of } 7 \text { March } 2002 \text { on the authorisation of } \\
\text { electronic communications networks and services; } \\
\text { (OJ L108/21, 24.4.2002) }\end{array}$ & $\begin{array}{l}\text { It responds to the need of reducing the regulatory burdens on market access and of ensuring a more consistent treatment of operators } \\
\text { by generating an official framework, which ensures the free will to provide electronic communications networks and services, } \\
\text { subject only to the limited conditions express in the Directive. In other words, individual rights of use should only be approved, or } \\
\text { limited in number, where there is a real need and when this occurs the procedures and selection criteria must be transparent and } \\
\text { respect the underlying principles of Community law; the administrative fees relating to undertakings should be limited to those } \\
\text { necessary to recover the actual administrative costs of the NRAs' activities }\end{array}$ \\
\hline $\begin{array}{l}\text { Directive 2002/22/EC of the European Parliament and of } \\
\text { the Council of } 7 \text { March } 2002 \text { on universal service and } \\
\text { users rights relating to electronic communications } \\
\text { networks and services; (OJ L108/51, 24.4.2002) }\end{array}$ & $\begin{array}{l}\text { It designs the regulatory setting to safeguard the interests of users, providing national regulatory authorities with the necessary } \\
\text { powers in order to minimise market distortions. Moreover, the universal service must be provided in a cost-effective manner and } \\
\text { just those services that are enclosed in the universal service obligation may be reimbursed through a contribution mechanism or } \\
\text { from public funds. Obligations should only be obligatory on operators with Significant Market Power (SMP) in a significant retai } \\
\text { market not effectively competitive, and where NRAs believe that obligations imposed at the wholesale level and/or carrier selection } \\
\text { and pre-selection are not performed under competitive conditions. }\end{array}$ \\
\hline $\begin{array}{l}\text { Commission Directive } 2002 / 77 / \mathrm{EC} \text { of } 16 \text { September } 2002 \\
\text { on competition in the markets for electronic } \\
\text { communications networks and services; (OJ L249/21, } \\
\text { 17.09.2002) }\end{array}$ & $\begin{array}{l}\text { It requires Member States to eliminate special or exclusive rights relating to electronic communications networks and services } \\
\text { (including those involving the use of frequencies) and to ensure that any operator is allowed to offer them, on objective, non- } \\
\text { discriminatory, proportionate and transparent criteria. It is worth noting that the Competition Directive concerns all networks and } \\
\text { services related to the delivery of signals by wire, radio, optical or other electromagnetic means (e.g. fixed, wireless, cable and } \\
\text { satellite networks) and to the so-called 'dark-fibre' networks, which enable third parties to transmit signals, using their own } \\
\text { switching or routing equipment. It hence applies to transmission networks and services used for broadcasting of radio and television } \\
\text { programmes, excluding services providing or exercising control over their content. }\end{array}$ \\
\hline
\end{tabular}


Table A2.1 - Regulatory setting by Country

\begin{tabular}{|c|c|c|c|c|c|c|c|c|c|c|c|c|}
\hline \multirow[t]{5}{*}{ Country } & \multicolumn{2}{|c|}{ Regulatory Framework } & \multicolumn{10}{|c|}{ Regulatory Governance } \\
\hline & \multirow[t]{4}{*}{ Industry regulator } & \multirow[t]{4}{*}{ Policy Maker } & \multicolumn{10}{|c|}{ Competencies } \\
\hline & & & \multicolumn{4}{|c|}{$\begin{array}{l}\text { Division of regulatory responsibilities for } \\
\text { licensing }\end{array}$} & \multicolumn{3}{|c|}{ Regulations on interconnection } & \multirow{2}{*}{\multicolumn{2}{|c|}{\begin{tabular}{|l} 
Regulations \\
on pricing \\
\end{tabular}}} & \multirow{3}{*}{$\begin{array}{l}\text { Regulations } \\
\text { the firm } \\
\text { performance } \\
\text { and costs on } \\
\text { service qualit }\end{array}$} \\
\hline & & & \multicolumn{2}{|c|}{ Issuing licence } & \multirow{2}{*}{\multicolumn{2}{|c|}{$\begin{array}{l}\text { Oversight of Approval of } \\
\text { licence } \\
\text { requirements }\end{array}$}} & \multirow{2}{*}{$\begin{array}{l}\text { Authorisation of } \\
\text { interconnection } \\
\text { charges of } \\
\text { operators with } \\
\text { significant } \\
\text { market power }\end{array}$} & \multirow{2}{*}{$\begin{array}{l}\text { Regulating } \\
\text { local loop } \\
\text { unbundling }\end{array}$} & \multirow[t]{2}{*}{$\begin{array}{c}\text { Dispute } \\
\text { resolution }\end{array}$} & & & \\
\hline & & & Fixed & Mobile & & & & & & $\begin{array}{l}\text { Type of } \\
\text { regulation }\end{array}$ & $\begin{array}{l}\text { Regulatory } \\
\text { Body }\end{array}$ & \\
\hline Austria & $\begin{array}{c}\text { RTRGmbH } \\
\text { Austrian Regulatory } \\
\text { Authority for } \\
\text { Telecommunications and } \\
\text { Broadcasting }\end{array}$ & $\begin{array}{c}\text { BMVIT } \\
\text { Federal Ministry } \\
\text { for Transport, } \\
\text { Innovation and } \\
\text { Technology }\end{array}$ & $\mathrm{R}$ & $\mathrm{R}$ & $\mathrm{R}$ & $\mathrm{C}, \mathrm{R}$ & $\mathrm{R}$ & $\mathrm{R}$ & $\mathrm{R}$ & $\begin{array}{c}\text { Tariff } \\
\text { Approval }\end{array}$ & $\mathrm{R}$ & $\mathrm{R}$ \\
\hline Belgium & $\begin{array}{c}\text { BIPT } \\
\text { Belgian Institute for } \\
\text { Postal Service and } \\
\text { Telecommunications }\end{array}$ & $\begin{array}{l}\text { FPS Economy, } \\
\text { SMEs, Self- } \\
\text { employed and } \\
\text { Energy }\end{array}$ & $\mathrm{R}$ & $\mathrm{R}$ & $\mathrm{R}$ & $\mathrm{C}$ & $\mathrm{R}$ & $\mathrm{R}$ & $\mathrm{C}$ & $\begin{array}{l}\text { Price } \\
\text { cap }\end{array}$ & $\mathrm{R}$ & $\mathrm{R}$ \\
\hline $\begin{array}{l}\text { Czech } \\
\text { Republic }\end{array}$ & $\begin{array}{c}\text { CTO } \\
\text { Czech } \\
\text { Telecommunications } \\
\text { Office }\end{array}$ & $\begin{array}{l}\text { Ministry of } \\
\text { Informatics }\end{array}$ & $\mathrm{R}$ & $\mathrm{R}$ & $\mathrm{R}$ & $\mathrm{C}, \mathrm{R}$ & $\mathrm{R}$ & $\mathrm{R}$ & $\mathrm{R}, \mathrm{C}$ & $\begin{array}{l}\text { Price } \\
\text { cap }\end{array}$ & $\mathrm{R}$ & $\mathrm{R}$ \\
\hline Denmark & $\begin{array}{c}\text { NTA } \\
\text { National IT and Telecom } \\
\text { Agency: as a part of } \\
\text { Ministry of Science, } \\
\text { Technology and } \\
\text { Innovation }\end{array}$ & $\begin{array}{l}\text { Ministry of } \\
\text { Science, } \\
\text { Technology and } \\
\text { Innovation }\end{array}$ & $\begin{array}{l:}\text { No licence } \\
\text { required } \\
\text { nor } \\
\text { registratio } \\
\text { n }\end{array}$ & $\mathrm{R}$ & $\mathrm{R}$ & $\mathrm{C}$ & $\mathrm{R}$ & $\mathrm{R}$ & $\mathrm{R}$ & $\begin{array}{l}\text { Price } \\
\text { cap }\end{array}$ & $\mathrm{R}$ & $\mathrm{R}$ \\
\hline France & $\begin{array}{c}\text { ARCEP } \\
\text { Autorité de Régulation } \\
\text { des Communications } \\
\text { Électroniques et des } \\
\text { Postes }\end{array}$ & $\begin{array}{c}\text { MINEFI } \\
\text { Ministry of the } \\
\text { Economy, Finance } \\
\text { and Industry }\end{array}$ & $\mathrm{R}$ & $\mathrm{R}$ & $\mathrm{R}$ & $\mathrm{C}$ & $\mathrm{R}$ & $\mathrm{R}$ & $\mathrm{R}$ & $\begin{array}{l}\text { Tariff } \\
\text { control }\end{array}$ & $\mathrm{R}$ & $\mathrm{R}$ \\
\hline Germany & $\begin{array}{c}\text { RegTP } \\
\text { Regulatory Authority for } \\
\text { Telecommunications and } \\
\text { Posts }\end{array}$ & $\begin{array}{c}\text { BMWA } \\
\text { Ministry of } \\
\text { Economics and } \\
\text { Labour }\end{array}$ & $\mathrm{R}$ & $\mathrm{R}$ & $\mathrm{R}$ & $\mathrm{C}, \mathrm{R}$ & $\mathrm{R}$ & $\mathrm{R}$ & $\mathrm{R}$ & $\begin{array}{c}\text { Price cap; } \\
\text { Tariff } \\
\text { Approval }\end{array}$ & 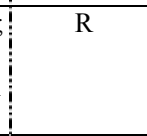 & $\mathrm{R}$ \\
\hline Greece & $\begin{array}{c}\text { EETT } \\
\text { National Post and } \\
\text { Telecommunications } \\
\text { Commission }\end{array}$ & $\begin{array}{c}\text { Ministry of } \\
\text { Transportation and } \\
\text { Communications }\end{array}$ & $\mathrm{R}$ & $\mathrm{R}$ & $\mathrm{R}$ & $\mathrm{C}, \mathrm{R}$ & $\mathrm{R}$ & $\mathrm{R}$ & $\mathrm{R}$ & $\begin{array}{l}\text { Price } \\
\text { cap }\end{array}$ & $\mathrm{R}$ & $\mathrm{R}$ \\
\hline
\end{tabular}


Table A2.2 - Regulatory setting by Country

\begin{tabular}{|c|c|c|c|c|c|c|c|c|c|c|c|c|}
\hline \multirow[t]{5}{*}{ Country } & \multicolumn{2}{|c|}{ Regulatory Framework } & \multicolumn{10}{|c|}{ Regulatory Governance } \\
\hline & \multirow[t]{4}{*}{ Industry regulator } & \multirow[t]{4}{*}{ Policy Maker } & \multicolumn{10}{|c|}{ Competencies } \\
\hline & & & \multicolumn{4}{|c|}{$\begin{array}{l}\text { Division of regulatory responsibilities for } \\
\text { licensing }\end{array}$} & \multicolumn{3}{|c|}{ Regulations on interconnection } & \multirow{2}{*}{\multicolumn{2}{|c|}{$\begin{array}{l}\text { Regulations } \\
\text { on pricing } \\
\end{array}$}} & \multirow{3}{*}{$\begin{array}{l}\text { Regulations } \\
\text { the firm } \\
\text { performance } \\
\text { and costs on } \\
\text { service quality }\end{array}$} \\
\hline & & & \multicolumn{2}{|c|}{$\begin{array}{l}\text { Issuing } \\
\text { licence }\end{array}$} & \multirow[t]{2}{*}{ Oversight of } & \multirow{2}{*}{$\begin{array}{l}\text { Approval of } \\
\text { Merger }\end{array}$} & \multirow{2}{*}{$\begin{array}{l}\text { Authorisation of } \\
\text { interconnection } \\
\text { charges of } \\
\text { operators with } \\
\text { significant } \\
\text { market power }\end{array}$} & \multirow{2}{*}{$\begin{array}{l}\text { Regulating } \\
\text { local loop } \\
\text { unbundling }\end{array}$} & \multirow[t]{2}{*}{\begin{tabular}{|l} 
Dispute \\
resolution
\end{tabular}} & & & \\
\hline & & & Fixed & Mobile & & & & & & $\begin{array}{l}\text { Type of } \\
\text { regulation }\end{array}$ & $\begin{array}{l}\text { Regulatory } \\
\text { Body }\end{array}$ & \\
\hline Hungary & $\begin{array}{c}\text { HIF } \\
\text { Communication } \\
\text { Authority }\end{array}$ & $\begin{array}{c}\text { Ministry of } \\
\text { Informatics and } \\
\text { Communication }\end{array}$ & $\mathrm{R}$ & $\mathrm{R}$ & $\mathrm{R}$ & $\mathrm{C}, \mathrm{R}$ & $\mathrm{R}$ & $\mathrm{R}$ & $\mathrm{R}$ & $\begin{array}{c}\text { Price } \\
\text { cap }\end{array}$ & $\mathrm{R}$ & $\mathrm{R}$ \\
\hline Ireland & $\begin{array}{c}\text { ComReg } \\
\text { Commission for } \\
\text { Communications } \\
\text { Regulation } \\
\end{array}$ & $\begin{array}{c}\text { Department of } \\
\text { Communications, } \\
\text { Marine and } \\
\text { Natural Resources } \\
\end{array}$ & $\mathrm{R}$ & $\mathrm{R}$ & $\mathrm{R}$ & $\mathrm{C}$ & $\mathrm{R}$ & $\mathrm{R}$ & $\mathrm{R}$ & $\begin{array}{l}\text { Price } \\
\text { cap }\end{array}$ & $\mathrm{R}$ & $\mathrm{R}$ \\
\hline Italy & $\begin{array}{c}\text { AGCOM } \\
\text { Autorita Garante nelle } \\
\text { Communicazioni } \\
\end{array}$ & $\begin{array}{c}\text { Ministry of } \\
\text { Communications }\end{array}$ & $\mathrm{M}$ & $\mathrm{M}$ & $\mathrm{M}$ & $\mathrm{C}, \mathrm{R}$ & $\mathrm{R}$ & $\mathrm{R}$ & $\mathrm{R}$ & $\begin{array}{c}\text { Price } \\
\text { cap }\end{array}$ & $\mathrm{R}$ & $\mathrm{R}$ \\
\hline Netherlands & $\begin{array}{c}\text { OPTA } \\
\text { Independent Post and } \\
\text { Telecommunications } \\
\text { Authority and Radio- } \\
\text { communications } \\
\text { Agency } \\
\end{array}$ & $\begin{array}{c}\text { Ministry of } \\
\text { Economic Affairs }\end{array}$ & $\begin{array}{c}\mathrm{R} \\
\text { (OPTA) } \\
\end{array}$ & \begin{tabular}{|c|}
$\mathrm{R}$ \\
Radio-- \\
commun \\
ications \\
Agency
\end{tabular} & 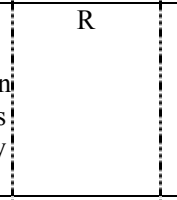 & $\mathrm{C}, \mathrm{R}$ & $\mathrm{R}$ & $\mathrm{R}$ & $\mathrm{R}$ & \begin{tabular}{|c|} 
Price \\
squeeze; \\
Tariff \\
Approval
\end{tabular} & $\mathrm{R}$ & $\mathrm{R}$ \\
\hline Poland & $\begin{array}{c}\text { URTiP } \\
\text { Office of } \\
\text { Telecommunications } \\
\text { and Post Regulation }\end{array}$ & $\begin{array}{l}\text { Ministry of } \\
\text { Infrastructure }\end{array}$ & $\mathrm{R}$ & $\mathrm{R}$ & $\mathrm{R}$ & $\mathrm{C}$ & $\mathrm{R}$ & $\mathrm{R}$ & $\mathrm{R}$ & $\begin{array}{c}\text { Tariff } \\
\text { Approval }\end{array}$ & $\mathrm{R}$ & $\mathrm{R}$ \\
\hline Portugal & $\begin{array}{c}\text { ANACOM } \\
\text { Autoridade Nacional } \\
\text { de Comunicações }\end{array}$ & $\begin{array}{c}\text { MOPTC } \\
\text { Ministry of Public } \\
\text { Works, Transport } \\
\text { and } \\
\text { Communications } \\
\end{array}$ & $\mathrm{R}$ & $\mathrm{R}$ & $\mathrm{R}$ & $\mathrm{C}, \mathrm{R}$ & $\mathrm{R}$ & $\mathrm{R}$ & $\mathrm{R}$ & $\begin{array}{c}\text { Tariff } \\
\text { Approval }\end{array}$ & $\mathrm{R}$ & $\mathrm{R}$ \\
\hline Spain & $\begin{array}{c}\text { CMT } \\
\text { Telecommunications } \\
\text { Market Commission } \\
\text { State Radio- } \\
\text { communications } \\
\text { Agency }^{3} \\
\end{array}$ & $\begin{array}{c}\text { Ministry of Industry, } \\
\text { Tourism and Trade } \\
\text { (State Secretariat for } \\
\text { Telecommunications } \\
\text { and the Information } \\
\text { Society) }{ }^{4}\end{array}$ & $\mathrm{R}$ & $\mathrm{M}$ & $\mathrm{R}$ & $\mathrm{C}, \mathrm{R}$ & $\mathrm{R}$ & $\mathrm{R}$ & $\mathrm{R}$ & $\begin{array}{c}\text { Price } \\
\text { cap }\end{array}$ & $\mathrm{R}$ & $\mathrm{M}$ \\
\hline
\end{tabular}


Table A2.3 - Regulatory setting by Country

\begin{tabular}{|c|c|c|c|c|c|c|c|c|c|c|c|c|}
\hline \multirow[t]{5}{*}{ Country } & \multicolumn{2}{|c|}{ Regulatory Framework } & \multicolumn{10}{|c|}{ Regulatory Governance } \\
\hline & \multirow[t]{4}{*}{ Industry regulator } & \multirow[t]{4}{*}{ Policy Maker } & \multicolumn{10}{|c|}{ Competencies } \\
\hline & & & \multicolumn{4}{|c|}{$\begin{array}{l}\text { Division of regulatory responsibilities for } \\
\text { licensing }\end{array}$} & \multicolumn{3}{|c|}{ Regulations on interconnection } & \multirow{2}{*}{\multicolumn{2}{|c|}{$\begin{array}{l}\text { Regulations } \\
\text { on pricing }\end{array}$}} & \multirow{3}{*}{$\begin{array}{l}\text { Regulations } \\
\text { the firm } \\
\text { performance } \\
\text { and costs on } \\
\text { service quality }\end{array}$} \\
\hline & & & \multicolumn{2}{|c|}{$\begin{array}{l}\text { Issuing } \\
\text { licence }\end{array}$} & \multirow{2}{*}{$\begin{array}{l}\text { Oversight of } \\
\text { licence } \\
\text { requirements }\end{array}$} & \multirow{2}{*}{$\begin{array}{l}\text { Approval of } \\
\text { Merger }\end{array}$} & \multirow{2}{*}{$\begin{array}{l}\text { Authorisation of } \\
\text { interconnection } \\
\text { charges of } \\
\text { operators with } \\
\text { significant } \\
\text { market power }\end{array}$} & \multirow{2}{*}{$\begin{array}{l}\text { Regulating } \\
\text { local loop } \\
\text { unbundling }\end{array}$} & \multirow[t]{2}{*}{$\begin{array}{c}\text { Dispute } \\
\text { resolution }\end{array}$} & & & \\
\hline & & & Fixed & Mobile & & & & & & $\begin{array}{l}\text { Type of } \\
\text { regulation }\end{array}$ & $\begin{array}{l}\text { Regulatory } \\
\text { Body }\end{array}$ & \\
\hline Sweden & $\begin{array}{c}\text { PTS } \\
\text { National Post and } \\
\text { Telecom agency }\end{array}$ & $\begin{array}{c}\text { Ministry of } \\
\text { Industry, } \\
\text { Employment and } \\
\text { Communications }\end{array}$ & $\mathrm{R}$ & $\mathrm{R}$ & $\mathrm{R}$ & $\mathrm{C}$ & $\mathrm{R}$ & $\mathrm{R}$ & $\mathrm{R}$ & $\begin{array}{c}\text { Tariff } \\
\text { Approval }\end{array}$ & $\mathrm{R}$ & $\mathrm{R}$ \\
\hline UK & $\begin{array}{c}\text { OFCOM } \\
\text { Office of } \\
\text { telecommunications }\end{array}$ & $\begin{array}{c}\text { DTI } \\
\text { Department of } \\
\text { Trade and Industry }\end{array}$ & $\mathrm{R}$ & $\mathrm{R}$ & $\mathrm{R}$ & $\mathrm{C}, \mathrm{R}$ & $\mathrm{R}$ & $\mathrm{R}$ & $\mathrm{R}$ & $\begin{array}{c}\text { Price } \\
\text { cap }\end{array}$ & $\mathrm{R}$ & $\mathrm{R}$ \\
\hline
\end{tabular}

Source: Elaboration on OECD (2006).

Notes:

1. M - Ministry, R - Regulator, C - Competition Authority.

2. As a convergence regulator, RTR-GmbH acts as the (KommAustria) as well as the Telekom Control Commission (TKK).

3. The State Radio-communications Agency has not been created yet, but its creation has been announced in the legislation (the same as follows).

4. The State Secretariat for Telecommunications and the Information Society, which is within the Ministry of Industry, Tourism and Trade,

5. Office of Telecommunications (Ottel); Radiocommunications Agency (RA); Independent Television Commission (ITC); Radio Authority (Rau) and

Broadcasting Standards Commission (BSC) were incorporated into Ofcom in 2003, which has responsibilities across television, radio.

Telecommunications and wireless communications services. 
Table A3 - National Regulatory Authorities: main issues

\begin{tabular}{|c|c|c|c|c|c|}
\hline Country & National Regulatory Authority & $\begin{array}{l}\text { Reporting } \\
\text { Obligations }\end{array}$ & $\begin{array}{l}\text { Source of } \\
\text { financing }\end{array}$ & $\begin{array}{l}\text { Appointment of the } \\
\text { Head of the } \\
\text { Regulatory Authority }\end{array}$ & $\begin{array}{l}\text { Jurisdiction } \\
\text { (Ability to overrrule the } \\
\text { regulator's decision) }\end{array}$ \\
\hline Austria & $\begin{array}{c}\text { RTRGmbH } \\
\text { Austrian Regulatory Authority for } \\
\text { Telecommunications and Broadcasting }\end{array}$ & $\begin{array}{l}\text { Legislature } \\
\text { and Ministry }\end{array}$ & $\begin{array}{l}\text { Appropriation } \\
\text { and contributions } \\
\text { from operators }\end{array}$ & The Minister & None \\
\hline Belgium & $\begin{array}{c}\text { BIPT } \\
\text { Belgian Institute for Postal Service and } \\
\text { Telecommunications }\end{array}$ & $\begin{array}{l}\text { Legislature } \\
\text { and Ministry }\end{array}$ & Fees & Council of Ministers & The Council of Ministers \\
\hline $\begin{array}{l}\text { Czech } \\
\text { Republic }\end{array}$ & $\begin{array}{c}\text { CTO } \\
\text { Czech Telecommunications Office }\end{array}$ & $\begin{array}{l}\text { Annual report to } \\
\text { the Government } \\
\text { and Parliament }\end{array}$ & Appropriation & $\begin{array}{l}\text { The Government upon } \\
\text { proposal of the Minister }\end{array}$ & None \\
\hline Denmark & $\begin{array}{c}\text { NTA } \\
\text { National IT and Telecom Agency: as a } \\
\text { part of Ministry of Science, } \\
\text { Technology and Innovation }\end{array}$ & Ministry & Appropriation & The Minister & $\begin{array}{l}\text { Telecommunications } \\
\text { Complaint Board }\end{array}$ \\
\hline France & $\begin{array}{c}\text { ARCEP } \\
\text { Autorité de Régulation des } \\
\text { Communications Électroniques et des } \\
\text { Postes }\end{array}$ & $\begin{array}{l}\text { Annual report to } \\
\text { the Government } \\
\text { and Parliament }\end{array}$ & Appropriation & $\begin{array}{l}\text { The President of the } \\
\text { National Assembly and } \\
\text { the President of the } \\
\text { Senate }\end{array}$ & None \\
\hline Germany & $\begin{array}{c}\text { RegTP } \\
\text { Regulatory Authority for } \\
\text { Telecommunications and Posts }\end{array}$ & $\begin{array}{l}\text { Legislature every } \\
2 \text { years }\end{array}$ & $\begin{array}{c}\text { Fees, } \\
\text { Appropriation } \\
\text { and contributions } \\
\text { from operators } \\
\end{array}$ & The President & None \\
\hline Greece & $\begin{array}{c}\text { EETT } \\
\text { National Post and Telecommunications } \\
\text { Commission }\end{array}$ & $\begin{array}{c}\text { Ministry } \\
\text { (Legislature) }\end{array}$ & Fees & The Minister & None \\
\hline Hungary & $\begin{array}{c}\text { HIF } \\
\text { Communication Authority }\end{array}$ & $\begin{array}{c}\text { Ministry } \\
\text { (Legislature) }\end{array}$ & Fees & The Prime Minister & The Minister \\
\hline Ireland & $\begin{array}{c}\text { ComReg } \\
\text { Commission for Communications } \\
\text { Regulation } \\
\end{array}$ & Ministry & $\begin{array}{c}\text { Fees and } \\
\text { contributions } \\
\text { from operators }\end{array}$ & The Minister & The Appeals Panel \\
\hline Italy & $\begin{array}{c}\text { AGCOM } \\
\text { Autorita Garante nelle } \\
\text { Communicazioni } \\
\end{array}$ & Legislature & $\begin{array}{c}\text { Fees and } \\
\text { appropriation }\end{array}$ & The President & None \\
\hline Netherlands & $\begin{array}{c}\text { OPTA } \\
\text { Independent Post and } \\
\text { Telecommunications Authority and } \\
\text { Radio-communications Agency }\end{array}$ & $\begin{array}{l}\text { Annual report } \\
\text { to the } \\
\text { Ministry }\end{array}$ & $\begin{array}{l}\text { OPTA: Fees, } \\
\text { Radio- } \\
\text { communications } \\
\text { Agency: Fees } \\
\text { and appropriation }\end{array}$ & $\begin{array}{l}\text { OPTA: The Crown; } \\
\text { Radio-communications } \\
\text { Agency: the Minister }\end{array}$ & None \\
\hline Poland & $\begin{array}{c}\text { URTiP } \\
\text { Office of Telecommunications and Post } \\
\text { Regulation }\end{array}$ & $\begin{array}{l}\text { Annual report } \\
\text { to the } \\
\text { Ministry }\end{array}$ & Appropriation & $\begin{array}{l}\text { The President of the } \\
\text { Council Ministers }\end{array}$ & None \\
\hline Portugal & $\begin{array}{c}\text { ANACOM } \\
\text { Autoridade Nacional de Comunicações }\end{array}$ & $\begin{array}{l}\text { Annual report } \\
\text { to the } \\
\text { Ministry and } \\
\text { Parliament }\end{array}$ & Fees & $\begin{array}{l}\text { The Council of } \\
\text { Ministers following a } \\
\text { proposal of the } \\
\text { Government member } \\
\text { responsible for } \\
\text { communications }\end{array}$ & None \\
\hline Spain & $\begin{array}{c}\text { CMT } \\
\text { Telecommunications Market } \\
\text { Commission }\end{array}$ & $\begin{array}{l}\text { Annual report } \\
\text { to the } \\
\text { Ministry and } \\
\text { Parliament } \\
\end{array}$ & $\begin{array}{l}\text { Contributions } \\
\text { from operators } \\
\text { based on their } \\
\text { turnover and fees }\end{array}$ & $\begin{array}{l}\text { The Government with } \\
\text { approval from the } \\
\text { Parliament }\end{array}$ & None \\
\hline Sweden & $\begin{array}{c}\text { PTS } \\
\text { National Post and Telecom agency }\end{array}$ & Ministry & $\begin{array}{l}\text { Contributions } \\
\text { from operators } \\
\text { based on their } \\
\text { turnover and fees }\end{array}$ & The Government & None \\
\hline UK & $\begin{array}{c}\text { OFCOM } \\
\text { Office of telecommunications }\end{array}$ & Legislature & $\begin{array}{l}\text { Fees and } \\
\text { contributions } \\
\text { from operators }\end{array}$ & $\begin{array}{l}\text { The secretariat of } \\
\text { State }\end{array}$ & None \\
\hline
\end{tabular}

Source: Elaboration on OECD (2006). 


\section{References}

Abate, A. and Clô, A. (2000). La regolazione elettrica in Italia: alcune prime valutazioni. L'industria. pp.709 ss.

Adler, N. and Golany, B. (2001). "Evaluation of deregulated airline networks using data envelopment analysis combined with principal component analysis with an application to Western Europe". European Journal of Operational Research, 132, 260-273.

Afonso, A.; Schuknecht, L. and Tanzi, V. (2005). Public Sector Efficiency: An International Comparison. Public Choice, 123 (3-4), 321-347.

Baldwin, R. and Cave, M.. (1999). Understanding Regulation. Oxford, Oxford University Press

Boylaud, O. and Nicoletti, G. (2000). Regulation, Market Structure and Performance in Telecommunications. OECD Economics Department Working Papers, No. 237. Paris, OECD Publishing.

Charnes, A.; Cooper, W. and Rhodes, E. (1978). Measuring the efficiency of decision making units. European Journal of Operational Research, 2 (6), 429-444.

Coelli, T., Rao, D. and Battese, G. (2002). An Introduction to Efficiency and Productivity Analysis. Massachusetts, Kluwer Academic Publishers.

European Commission (2006). Report on European Electronic Communications Regulation and Markets 2005 (11th Report). Brussels, European Commission.

Edwards, G. and Waverman, L. (2004). The Effects of Public Ownership and Regulatory Independence on Regulatory Outcomes. A Study of Interconnect Rates in EU Telecommunications. December, mimeo.

Everitt, B. and Dunn, G. (1991). Applied Multivariate Data analysis, John Wiley \& Sons, London.

Farrell, M. (1957). The Measurement of Productive Efficiency. Journal of the Royal Statistical Society, series A, General, 120, 253-81.

Gilardi, F. (2005). Delegation to Independent Regulatory Agencies in Western Europe: Credibility, Political Uncertainty, and Diffusion, in Braun, D. and Gilardi, F. (eds). Delegation in Contemporary Democracies. London, Routledge

Gual, J. and Trillas, F. (2004). Telecommunications Policies: Determinants and impact. CEPR Discussion Paper No. 4578, London. 
Hall, P. and Taylor, R. (1996). Political Science and the Three New Institutionalism. Political Studies, 44, 936-957.

Hayes, K.; Razzolini, L. and Ross, L. (1998). Bureaucratic choice and nonoptimal provision of public goods: Theory and evidence. Public Choice 94, 1-20.

Henisz, W. (2000). The Institutional Environment for Economic Growth. Economics and Politics, 12 (1), 1-31.

Henisz, W. (2002). The Institutional Environment for Infrastructure Investment. Industrial and Corporate Change, 11 (2), 355-389.

Henisz, W. and Zelner, B. (2001). The Institutional Environment for Telecommunications Investment. Journal of Economics and Management Strategy 10 (1), 123-147.

International Telecommunications Union. (2005). Trends in Telecommunication Reform 2004/2005 Licensing in an Era of Convergence (Summary): 6.

Jollife, I. (1972) "Discarding variables in a principal component analysis 1: Artificial data", Applied Statistics, 21, 160-173.

Koelbe, T. (1995). The New Institutionalism in Political Science and Sociology. Comparative Politics, 27 (2), 231-243.

La Spina, A. and Majone, G. (2000). Lo Stato regolatore. Bologna, Il Mulino.

Levy, B. and Spiller, P. (1994). The Institutional Foundations of Regulatory Commitment: A Comparative Analysis of Telecommunications Regulation. Journal of Law, Economics and Organization, 10 (2), 201-246.

Levy, B. and Spiller, P.T. (1996). Regulations, Institutions and Commitment: Comparative Studies of Telecommunications. Cambridge, UK, Cambridge University Press.

Majone, G. (2001). Nonmajoritarian Institutions and the Limits of Democratic Governance: A Political Transaction-Cost Approach. Journal of Institutional and Theoretical Economics $157,57-78$.

Napolitano, G. (2005). Regole e mercato nei servizi pubblici. Bologna, Il Mulino.

Newbery, D.M. (2000). Privatization, Restructuring, and Regulation of Network Utilities. Cambridge, Massachusetts, MIT Press. 
Nicoletti, G. and Scarpetta, S. (2005). Regulation and Economic Performance: Product Market Reforms and Productivity in the OECD. OECD Economics Department Working Papers, No. 460. Paris, OECD Publishing.

North, D.C. (1990). Institutions, Institutional Change and Economic Performance. Cambridge, Massachusetts, Harward University Press.

OECD (2000). Telecommunication regulatory institutional structures and responsibilities, Paris, May.

OECD (2005). Communications Outlook 2005. Paris.

OECD (2006). Telecommunication regulatory institutional structures and responsibilities, Paris, January.

Oglietti, A. and Pontarollo, E. (2000). La performance dell'Autorità per le Garanzie nelle comunicazioni: un primo esame. L'industria, pp.765 ss.

Oglietti, A. and Pontarollo, E. (2003). Criteri per l'analisi e la valutazione delle Autorità di regolazione, in Oglietti, A. and Pontarollo, E., (eds) Regole e regolatori nelle telecomunicazioni europee. Bologna, Il Mulino.

Smith, W. (1997). Utility Regulators: the independence debate. Public policy for the private sector. World Bank Note No.127. Washington.

Stern, J. and Cubbin, J. (2003). "Regulatory Effectiveness: The Impact of Regulation and Regulatory Governance Arrangements on Electricity Industry Outcomes: A Review Paper. London Business School Regulation Initiative, Working Paper No. 56.

Thanassoulis, E. (2001). Introduction to the Theory and Application of Data Envelopment Analysis, Kluwer Academic Publishers.

Thatcher, M. (1999). The Politics of Telecommunications. Oxford, Oxford University Press.

World Trade Organization (WTO). (1996). Reference Paper on Telecommunications. http://www.wto.org/english/tratop_e/serv_e/telecom_e/tel23 e.htm 


\section{Annex - Data and Sources}

Table 1.1 - Original data set for the CRPIsc (2005)

\begin{tabular}{|c|c|c|c|c|c|c|c|c|c|c|c|}
\hline & \multicolumn{7}{|c|}{ Effectiveness of the national regulatory system } & \multicolumn{4}{|c|}{ Effectiveness of the dispute settlement body } \\
\hline & $1 /$ & $2 /$ & $3 /$ & 4/ & $5 /$ & $6 /$ & $7 /$ & $8 /$ & 9/ & $10 /$ & $11 /$ \\
\hline Austria & 25.0 & 26.3 & 15.0 & 7.5 & 8.0 & 17.5 & 17.5 & 7.5 & 10.0 & 10.0 & 15.0 \\
\hline Belgium & 20.0 & 11.0 & 2.5 & 10.0 & 6.0 & 5.0 & 20.0 & 12.5 & 7.5 & 10.0 & 25.0 \\
\hline Czech Republic & 27.5 & 36.0 & 2.5 & 10.0 & 4.0 & 5.0 & 25.0 & 5.0 & 10.0 & 5.0 & 20.0 \\
\hline Denmark & 25.0 & 36.0 & 7.5 & 15.0 & 7.0 & 7.5 & 27.5 & 12.5 & 10.0 & 15.0 & 25.0 \\
\hline France & 22.5 & 22.3 & 7.5 & 12.5 & 8.0 & 21.5 & 25.0 & 12.5 & 10.0 & 10.0 & 25.0 \\
\hline Germany & 12.5 & 17.3 & 7.5 & 2.5 & 6.0 & 11.5 & 2.5 & 14.0 & 10.0 & 10.0 & 10.0 \\
\hline Greece & 27.5 & 14.8 & 0.0 & 10.0 & 8.0 & 11.5 & 10.0 & 2.5 & 10.0 & 15.0 & 15.0 \\
\hline Hungary & 30.0 & 29.8 & 5.0 & 10.0 & 4.0 & 22.5 & 25.0 & 14.0 & 7.5 & 5.0 & 15.0 \\
\hline Ireland & 35.0 & 32.5 & 7.5 & 10.0 & 8.0 & 12.5 & 12.5 & 10.0 & 10.0 & & 10.0 \\
\hline Italy & 32.5 & 28.5 & 7.5 & 12.5 & 7.0 & 5.0 & 20.0 & 2.5 & 10.0 & 10.0 & 15.0 \\
\hline Netherlands & 27.5 & 27.3 & 7.5 & 10.0 & 6.0 & 5.0 & 12.5 & 7.5 & 10.0 & 15.0 & 15.0 \\
\hline Poland & 35.0 & 31.0 & 2.5 & 10.0 & 4.0 & 5.0 & 30.0 & & 10.0 & 10.0 & 15.0 \\
\hline Portugal & 25.0 & 19.8 & 7.5 & 15.0 & 8.0 & 20.0 & 22.5 & 10.0 & 10.0 & 15.0 & 20.0 \\
\hline Spain & 22.5 & 32.3 & 7.5 & 12.5 & 6.0 & 5.0 & 15.0 & 10.0 & 10.0 & 12.5 & 10.0 \\
\hline Sweden & 32.5 & 26.5 & 5.0 & 12.5 & 8.0 & 17.5 & 22.5 & 5.0 & 10.0 & 5.0 & 12.5 \\
\hline UK & 30.0 & 34.0 & 2.5 & 15.0 & 8.0 & 25.0 & 32.5 & 10.0 & 10.0 & & 30.0 \\
\hline Mean & 26.9 & 26.6 & 5.9 & 10.9 & 6.6 & 12.3 & 20.0 & 9.0 & 9.7 & 10.5 & 17.3 \\
\hline Minimum & 12.5 & 11.0 & 0.0 & 2.5 & 4.0 & 5.0 & 2.5 & 2.5 & 7.5 & 5.0 & 10.0 \\
\hline Maximum & 35.0 & 36.0 & 15.0 & 15.0 & 8.0 & 25.0 & 32.5 & 14.0 & 10.0 & 15.0 & 30.0 \\
\hline
\end{tabular}

1/ Transparency.

2/ Independence of regulator.

3/ Speed of process.

4/ Powers and sanctions.

5/ Scale of resources.

6/ Compliance with market analysis requirements and imposition of remedies.

7/ Effectiveness of appeal process.

8/ Speed of dispute process.

9/ Due process.

10/ Effectiveness of sanctions.

11/ Effectiveness of appeal process.

Source: SCORECARD Annual Report, 2005. European Telecommunications Association (ECTA). 
Table 1.2 - Original data set for the CRPIsc (2005)

\begin{tabular}{|c|c|c|c|c|c|c|c|c|c|c|}
\hline & \multicolumn{6}{|c|}{ General market access conditions } & \multicolumn{4}{|c|}{ Access to products } \\
\hline & $1 /$ & $2 /$ & $3 /$ & $4 /$ & $5 /$ & $6 /$ & $7 /$ & $8 /$ & 9/ & $10 /$ \\
\hline Austria & 15.0 & 15.0 & 12.5 & 5.0 & 10.0 & 17.5 & 20.0 & 18.0 & 22.0 & 40.0 \\
\hline Belgium & 10.0 & 7.5 & 7.5 & & 7.5 & 22.5 & 15.0 & 7.0 & 19.5 & 45.0 \\
\hline Czech Republic & 2.5 & 5.0 & 7.5 & 7.5 & 10.0 & 3.8 & 22.5 & & 12.5 & 12.5 \\
\hline Denmark & 17.5 & 14.0 & 10.0 & & 15.0 & 17.5 & 25.0 & 17.0 & 37.0 & 40.0 \\
\hline France & 9.0 & 16.5 & 10.0 & 2.5 & 7.5 & 10.0 & 16.3 & 21.0 & 16.0 & 45.0 \\
\hline Germany & 5.0 & 7.5 & 7.5 & & 15.0 & 25.0 & 5.0 & & 19.5 & 12.5 \\
\hline Greece & 5.0 & 7.5 & 2.5 & 5.0 & 5.0 & 15.0 & 12.5 & 7.0 & 12.0 & 45.0 \\
\hline Hungary & 5.0 & 7.5 & 7.5 & 5.0 & 7.5 & 10.0 & 15.0 & 7.0 & 11.5 & 52.5 \\
\hline Ireland & 14.0 & 8.8 & 12.5 & 17.5 & 15.0 & 12.5 & 12.5 & 12.0 & 30.5 & 25.0 \\
\hline Italy & 12.5 & 17.5 & 5.0 & 7.5 & & 20.0 & 15.0 & 10.0 & 20.5 & 17.5 \\
\hline Netherlands & 12.5 & 13.8 & 12.5 & & 15.0 & 15.0 & 5.0 & 9.0 & 25.0 & 32.5 \\
\hline Poland & 7.5 & 12.5 & 2.5 & 2.5 & 10.0 & 5.0 & 12.5 & & 12.5 & 30.0 \\
\hline Portugal & 11.5 & 15.0 & & 5.0 & 2.5 & 17.5 & 12.5 & 17.0 & 16.0 & 42.5 \\
\hline Spain & 6.3 & 14.0 & 5.0 & 5.0 & 5.0 & 20.0 & 17.5 & 10.0 & 10.5 & 27.5 \\
\hline Sweden & 10.0 & 12.5 & 7.5 & 5.0 & 10.0 & 20.0 & 22.5 & 3.0 & 27.0 & 15.0 \\
\hline UK & 17.5 & 19.0 & 12.5 & 20.0 & 15.0 & 22.5 & 22.5 & 22.0 & 34.5 & 27.5 \\
\hline Mean & 10.0 & 12.1 & 8.2 & 7.3 & 10.0 & 15.9 & 15.7 & 12.3 & 20.4 & 31.9 \\
\hline Minimum & 2.5 & 5.0 & 2.5 & 2.5 & 2.5 & 3.8 & 5.0 & 3.0 & 10.5 & 12.5 \\
\hline Maximum & 17.5 & 19.0 & 12.5 & 20.0 & 15.0 & 25.0 & 25.0 & 22.0 & 37.0 & 52.5 \\
\hline
\end{tabular}

1/ Access obligations.

2/ Non discrimination and price squeeze.

3/ Price control.

4/ Accounting separation.

5/ Rights of way and facility sharing.

6/ Numbering.

7/ Mobile.

8/ Business.

9/ Narrow Band Voice

10/ Broadband.

Source: SCORECARD Annual Report, 2005. European Telecommunications Association (ECTA). 
Table 2 - Original data set for the CRPIeuri (2004)

\begin{tabular}{lcc}
\hline Country & \multicolumn{2}{c}{ EURI Indexes } \\
\cline { 2 - 3 } & $\begin{array}{c}\text { Regulatory Independence } \\
\text { Indexes }\end{array}$ & $\begin{array}{c}\text { Regulatory Quality } \\
\text { Indexes }\end{array}$ \\
\cline { 2 - 3 } & EURI-I & EURI-Q \\
\hline Austria & 5.00 & 3.00 \\
Belgium & 4.50 & 3.00 \\
Denmark & 5.75 & 5.00 \\
France & 6.50 & 2.33 \\
Germany & 8.00 & 2.67 \\
Greece & 7.50 & 3.00 \\
Ireland & 8.50 & 4.00 \\
Italy & 10.25 & 0.67 \\
Netherlands & 7.75 & 4.00 \\
Portugal & 9.50 & 4.00 \\
Spain & 6.75 & 1.67 \\
Sweden & 8.75 & 4.00 \\
UK & 5.75 & 4.67 \\
\hline Mean & 7.27 & 3.23 \\
Minimum & 4.50 & 0.67 \\
Maximum & 10.25 & 5.00 \\
\hline
\end{tabular}

Source: London Business School Regulation Initiative Research Group. 